\title{
KUR'AN'DA KARDEŞLİĞİN İNSANî VE AHLÂKÎ TEMELLERİ
}

\section{ADİL BOR*}

$\ddot{\mathbf{O z}}$

Bu makalede Kur'an'ın nazil olmasıyla birlikte oluşan kardeşliğin mahiyeti, genel anlamda Kur'an'da bahsedilen kardeşlik türleri, bunları oluşturan temel ilkeler ve bunun bir sonucu olarak insanların ilişkilerinde meydana gelmesi gereken değişimler tetkik edilmiştir. Öncelikle Kur'an ile birlikte oluşan kardeşliğin temel dayanaklarının bulunup bulunmadığı şayet bu kardeşliğin temel parametreleri varsa bunların neler olabileceği üzerinde durulmuştur. Fikir hürriyetinin sağlandığı ortamın oluşturulması, insan onurunun korunması, adalete tanıklığın yapılması, ihtilaflar vuku bulduğunda çözüm odaklı düşünülmesi, iyinin yanında, kötünün ise karşısında durulması, hoşgörülü olunması, beşerî ilişkilerde sayg1 dilinin kullanılması ve dürüst olunması gibi değerlerin Kur'an ile birlikte oluşan kardeşliğin temel prensipleri olup olmadığ sonra çalışmada Kur'an-1 Kerim'deki konuyla ilgili ayetlerden, bu âyetlerle ilgili tefsir kitaplarında yer alan yorumlardan, konu ile ilgili hadislerden ve genel anlamda kardeşlik ve kardeşlik hukukuyla ilgili yapılan çalışmalardan yararlanılarak bir senteze varma yöntemi kullanılmıştır. Bunun neticesinde Kur'an'da insan olmaktan ve inançtan kaynaklanan kardeşlik türleri, merhametli olmak, adalete tanıklık etmek gibi yukarıda zikredilen niteliklerin, kardeşliğin insanî ve ahlâkî temel prensipleri oldukları sonucuna varılmıştır.

Anahtar Kelimeler: Kur'an, kardeşlik, insan, ahlâk.

\section{HUMANISTIC AND MORAL FOUNDATIONS OF THE BROTHERHOOD IN THE QUR'AN}

\begin{abstract}
In this article, nature of the brotherhood formed by the Qur'an and the forms of fraternity mentioned in the Qur'an in general terms and the basic principles that constitute them, and the changes that people should make in their relations as a result have been axamined. Firstly, it will be emphasized that the basic foundations of the brotherhood that co-exist with the Qur'an are present or not, and if there are basic parameters of this brotherhood, what are those can be. The values such as freedom of opinion that is provided or not, the protection of human dignity, the making of just testimony, the thinking of solution oriented when conflicts arise, being by the side of goodness, being against the wrong, being tolerant, using respectful language in human relations and being honest are the foundation of brotherhood it has been tried to determine whether or not there are principles. After then the study, there is a method of reaching a synthesis by using the related Qur'anic verses, the commentaries in the Qur'anic verses related to
\end{abstract}

Makale Gönderim Tarihi: 22.04.2018, Kabul Tarihi: 16.08.2018

Doi: $10.26791 /$ sarkiat.417788

* Dr. Adil BOR, Diyanet İşleri Başkanlığı, Haseki Dini Yüksek İhtisas Merkezi Müdürü, adilbor@hotmail.com.

ORCID ID: 0000-0002-8784-5035 
these verses, the hadiths related to Qur'an and the studies related to brotherhood and brotherhood in general terms. As a result, in the Qur'an, the above-mentioned qualities, such as brotherhoods originating from humanity and belief, being compassionate, witnessing adherence, came to the conclusion that they are the basic human and moral principles of brotherhood.

Keywords: The Qur'an, brotherhood, human, moral.

\section{Giriş}

Allah, insanı akıl ve irade ile donatıp yeryüzüne yerleştirdikten sonra peygamberler aracığıyla kendisiyle iletişim halinde olmuştur. İnsanın güven içinde bir hayat geçirebilmesi ve kendisine tevdi edilen dünya imarını layıkıyla gerçekleştirebilmesi için insana rehberlik edecek vahiy göndermiştir. Çünkü insanın yapısı ve aklî melekesi doğru bir yaşam biçiminin bütün gereklerini, bütün ayrıntılarıyla bulabilecek bir yeterliliğe sahip değildir. Peygamberlere duyulan ihtiyaç da aslında insanın bu yapısından kaynaklanmaktadır.

İnsanlık tarihinde İslâm olarak isimlendirilen dinin temel ilkelerini ihtiva eden Kur'an-1 Kerîm, bireysel ve toplumsal ilişkilerde olduğu gibi kardeşliğin insanî ve ahlâkî boyutları hususunda da insanlara rehberlik yapabilecek bir mahiyettedir. İnsanlar arasında birlik ve dostluğun tesis edildiği, hak ve adaletin tahakkuk ettiği, emniyet ve güvenin hâkim olduğu bir toplumun oluşumuna yönelik Kur'an'da bulunan birçok emir ve tavsiye de bunu teyit etmektedir. ${ }^{1}$ Ancak burada dikkat çeken en önemli husus, Kur'an tasavvurunda ırk, kabile, bölge ve rengin değil, İslâmî ve insanî değerlerin ölçü olarak kabul edilmiş olmasıdır. ${ }^{2}$

Kur'an'ın nüzulüyle birlikte Medine'de oluşan ilk Müslüman toplum, hem insan olmaktan hem de inançtan kaynaklanan kardeşliğin insanî ve ahlâkî ilkeleri üzerine bina edilmiştir. $\mathrm{Bu}$ çerçevede inanç eksenli kardeşlik sözleşmesiyle Habeşistanlı Bilal, Rum kökenli Suheyb, Fars kökenli Selman ve Arap kökenli Kureyşliler, Evs ve Hazreçliler arasında kardeşlik tesis edilmiştir. Medine vesikası ile de insan olmaktan kaynaklanan kardeşlik bilinci oluşturulmuştur. Böylelikle insanlar arasında kardeşlik hukuku karşılıklı olarak gelişmiştir. Özellikle Medine vesikasında Müslüman olsun veya olmasın bütün bireyler toplumun birer ferdi olarak kabul edilmiştir. Birbirlerinin sevincine ve sıkıntılarına ortak olmada ve güvenli bir ortamın oluşmasında sorumlulukları söz konusu olmuştur. Neticede kardeşlik ve beraber yaşama duyguları gelişmiştir.

Medine'de inşa olunan bu kardeşlik anlayışı tarihî süreç içinde ırk, mezhep ve meşreplere olan hastalıklı bakış açısından dolayı bozulmuş ve bunun sonucunda her grup kendine has bir alan oluşturmuştur. Böylelikle Kur'an'da belirtilen ve herkesi kuşatan kardeşliğin temel ilkelerinin esas alınmasından ziyade özel anlamda mezhep ve meşrep ekseninde kardeşlik duyguları gelişmiştir. Bunun bir sonucu olarak Müslümanların kardeşliği ve dolayısıyla birlikleri bozulmuştur. $\mathrm{Bu}$ duruma, hilafet tartışmaları sonucunda meydana gelen bölünmeler ve Emevilerin yönetimi ele geçirip kardeşliğin temel prensipleri yerine, Arap asabiyetini ön plana çıkarmaları ve Arap olmayan Müslümanları mevâlî olarak isimlendirmeleri örnek olarak gösterilebilir.

\footnotetext{
1 Âl-i İmrân, 3/103; Nisâ, 4/175; Hac, 22/ 78.

2 Hucurât, 49/ 13.
} 
$\mathrm{Bu}$ makalede günümüzde zedelenmiş olan insan ve İslâm kardeşliği problematiğine katkısını umarak Kur'an'da kardeşliğin hangi temeller üzerine bina edildiği hususunda yapılan arşiv araştırmasında konuyla ilgili herhangi bir çalışmanın olmadığı görülmüştür. Bundan dolayı makalede herkesi kuşatacak ve aynı zamanda devam edebilen bir kardeşliğin nasıl oluşabileceği ve bunun temellerinin neler olabileceği üzerinde durulacaktır. Makalemizin başlığından da anlaşacağı üzere yöntem olarak çalışmamız âyetler ve bu âyetlerle ilgili tefsirlerde yer alan bilgiler ekseninde şekillenecektir. Ayrıca çalışmamızda kardeşlik ile ilgili olan hadislerden ve konuyla ilgili yapılmış çalışmalardan da yararlanılacaktır. Konun daha iyi anlaşılması için öncelikle Kur'an'da kardeşlik türlerinden bahsedilmesi faydalı olacaktır.

\section{Kur'an'a Göre Kardeşlik Türleri}

Kur'an-1 Kerîm'in muhatabı insan olduğu için Kur'an'daki bütün emir ve tavsiyeler, doğrudan veya dolaylı olarak insanla ilgilidir. Tevhit inancı ekseninde toplum ve bireylerin ilişkisini düzenlemek, güveni tesis etmek, adaleti esas alan toplumsal bir hayatı oluşturmak ve böylelikle dünya imarını, nitelikli bir şekilde gerçekleştirmek, Kur'an'ın öncelikli amaçları arasında yer almaktadır. Ancak bunların gerçekleşebilmesi için öncelikle insan olmaktan ve inançtan kaynaklanan kardeşliğin, sağlam temeller üzerine bina edilmesi gerekir.

Kur'an'da kardeşlik, ihvân/ إخْوَانُ ve ihve/ إخوَةُ kelimeleri ile ifade edilmektedir. $\mathrm{Bu}$ kelimeler, aynı anne-babadan, bunların birinden veya süt emzirme yoluyla gerçekleşen kardeşliği ifade etmektedirler. ${ }^{3}$ Bununla birlikte ihve kelimesi, genel anlamda nesep kardeşliğini ${ }^{4}$ belirtirken, ihvân, farklı şekillerde oluşan dostluk ve kardeşlikleri ifade etme yanında ${ }^{5}$ mecâzi olarak aynı kabileye mensup olan, aynı dine inanan, aynı sanat ve işi benimseyen, aynı düşünce ve değerleri paylaşan kişilerin oluşturduğu kardeşlik türlerini ifade etmek için de mevzubahis olmaktadır. ${ }^{6}$ Bundan dolayı ihve kelimesinin sadece din kardeşliğini ve ihvân kelimesinin de dostluğu ifade ettiğini söylemek doğru bir tespit değildir. ${ }^{7}$

Kuran-1 Kerîm'de insan olmaktan kaynaklanan kardeşlik dışında inanç kardeşliği ${ }^{8}{ }^{8}$ düşünce birliğ $i^{9}$ ve mali imkânlara dayalı olarak oluşan kardeşlik, ${ }^{10}$ Medine'deki Müslüman toplumu yıkmaya yönelik çalışan grubun kardeşliği ${ }^{11}$ ve cennete gidecek olanların kardeşliğinden ${ }^{12}$ de bahsedilmektedir. Bu kardeşlik nevileri genelde ihvân/ إخْوَانُ ve ihve/ إخوَةُ kelimeleriyle ifade edilmektedirler.

\footnotetext{
3 Yûsuf, 12/8-63-65-69; A'râf, 7/111-142; Mâide, 5/25-30-31; Yûnus, 10/87. Ayrica Kur'an bağlamında eh/إخانْوَانُ ve ihve/ ihvân velimelerinin kullanımlarını detaylı bir şekilde görebilmek için bk. Muhammed Fuâd Abdulbâkî, el-Mu'cemu'l-Mufehres li Elfâzi'l-Kur'an-i'lKerîm, Dâru'l-Hadis, Kahire, 1987, s. 30-31.

${ }^{4}$ Nisâ, 4/11-176; Yûsuf, 12/58.

5 İbn Manzûr, Ebü'l-Fazl Muhammed b. Mükerrem b. Alî el-Ensârî, Lisânu'l-Arab, Dâru İhyâi'tTurâsi'l-Arabî, Beyrut, 1997, I, 90-91.

6 İsfahânî, Ebü'l-Kāsım Hüseyin b. Muhammed b. el-Mufaddal er-Râgıb, Mufredâtu Elfâzi'lKur'ân, Safvân Adnan Dâvûdî (thk.), Dâru'l-Kalem, Dımaşk, 2002, s. 68.

${ }^{7}$ Ebû Hayyân Muhammed b. Yûsuf b. Alî b. Yûsuf b. Hayyân el-Endelüsî, el-Bahrü'l-Muhît Mektebetu'n-Nasr el-Hadîse, Riyâd, ts., V, 14-15.

${ }^{8}$ Hucurât, 49/10; Ahzâb, 33/ 5.

9 Haşr, 59/11; Tevbe, 9/67; Ahzâb, 33/18.

10 İsrâ, 17/37.

11 Ahzâb, 33/18.

12 Hicr, 15/47.
} 
Ancak bütün bu kardeşlik türlerinden bahsetmek makalenin sınırlarını aşacağından çalışmamızda insanların kardeşliği ile Müslümanların kardeşliğini ve bunların temellerini oluşturan insanî ve ahlâkî esasları ele almakla yetineceğiz.

\section{1. İnsan kardeşliği}

İslâm'da yaratılış açısından insanlar eşittirler ve bu açıdan hiçbir ferdin diğerine üstünlüğü söz konusu değildir. Bu bakış açısını ortaya koyan birçok âyet bulunmakla birlikte ${ }^{13}$ bu âyetlerden birkaç tanesini zikretmekle yetineceğiz. Nisâ sûresinde bu hususta şöyle denilmektedir: "Ey insanlar! Sizi bir tek nefisten yaratan, aynı nefisten eşini de yaratan ve böylelikle sayısız erkek ve kadın meydana getiren rabbinize itaatsizlikten sakınin"14 âyetidir. Bu âyette geçen "nefs" kelimesi çoğunlukla Âdem ve "zevc" kelimesi Havvâ olarak tefsir edilmektedir. ${ }^{15}$ Ancak nefs kelimesini cins/öz olarak yorumlayanlar da olmuştur. ${ }^{16}$ Buna göre bütün insanlar Âdem ve Havvâ'ın çocuklarıdır ve onlar da topraktan yaratılmışlardır. Ancak birinci yorum âyetin zahiriyle daha çok uygunluk arz etmektedir.

Nesep açısından insanlar arasında herhangi bir farkın olmadığını, "Ey insanlar! Doğrusu biz sizi bir erkekle bir dişiden yarattık. Ve birbirinizle tanışmanız ve yardımlaşmanı için sizi kavimlere ve kabilelere ayırdık. Ama şunu bilin ki Allah katında en değerli olanınız, O'nun emir ve yasaklart hususunda en duyarl, en dikkatli olanınızdır. Şüphesiz Allah her şeyi bilen, her şeyden haberdar olandır"17 âyeti de açık bir şekilde ifade etmektedir. Bu âyette yer alan "şu'ûb" kelimesi uzak nesebi, kabilenin ise yakın akrabaları ifade ettiğine, bunun bir üstünlük vesilesi değil, sosyolojik bir olgu olduğuna ve insanların değerli olmaları ilâhî ve insanî değerleri yaşayıp yaşamamalarına göre değerlendirilebileceğine işaret edilmektedir. ${ }^{18}$ Zemahşerî'nin (ö.538/1144) de belirttiği gibi insanların değerli oluşları neseplerine göre değil, İslâmî ve insanî değerlere göredir. ${ }^{19}$

13 Bakara, 2/21; Hucurât 49/13; Yûnus 10/108; A 'râf 7/158; Nisâ 4/170. Bütün bu âyetler, "Ey insanlar" hitabıyla başlamakta ve daha sonra bütün insanları ilgilendiren ibadet, peygamberlerin gönderilmesi ve vahiy gibi konular ifade edilmektedir. Bütün insanları kapsayan insan kavramından sonra herkes için söz konusu olan meselelerin zikredilmesi, insanların yaratılış açısından aynı haklara sahip olduklarının bir ifadesidir.

${ }^{14}$ Nisâ, 4/1.

15 Taberî, Ebû Cafer İbn Cerîr Muhammed b. Cerîr b. Yezid, Câmi 'u'l-Beyân 'an Te'vîli Âyi'lKur'ân, Mahmut Muhammed Şâkir ve Ahmet Muhammed Şakir (thk.), Mektebetü İbnTeymiyye, Kahire, ts., III, 566; Zemahşerî, Ebü'l-Kâsım Cârullah Mahmûd b. Ömer b. Muhammed, el-Keşşâf an Hakâikı Gavâmizi't-Tenzîl ve 'Uyûni'l-Ekâvil fî̀ Vücûhi't-Te'vil; Dâru'l-Kutûbi'l-İlmiyye, Beyrut, 2015, I, 451; İbn Atiyye, Ebû Muhammed Abdülhak b. Gālib b. Abdirrahmân b. Gālib elMuhâribî el-Gırnâtî el-Endelüsî, el-Muharreru'l-Vecîz fî Tefsîri Kitabi'l-Azîz, Abdusselâm Abduşşâfî̀ (thk.), Dâru'l-Kutûbi'l-İlmiyye, Beyrut, 2001, II, 4; el-Kurtûbî, Ebû Abdillâh Muhammed b. Ahmed b. Ebî Bekr b. Ferh, el-Câmi' li-Ahkâmi'l-Ķur'ân, Abdullah b. Abdulmuhsin et-Türkî (thk.), Muessesetu Risâle, Beyrut, 2013; VI, 6-7.

${ }^{16}$ Râzî, Ebû Abdullah Fahreddin Muhammed b. Ömer Fahreddin, Mefâtihu'l-Gayb, Dâru'l-Fikr, Beyrut, 1981, XIX, 167.

17 Hucurât, 49/13.

18 Taberî, Câmi 'u'l-Beyân, XX, 387.

19 Zemahşerî, el-Keşşâf, IV, 365. Ayrıca bk. Mukâtil b. Süleyman, Tefsîr-i Kebîr, Dâru'l-Kutûbi'lİlmiyye, Beyrut, ts., III, 263; Maturîdî, Ebû Mansûr Muhammed b. Muhammed b. Mahmûd Semerkândî, Te'vilâtu'l-Kur'an, Bekir Topaloğlu ve Ahmed Vanlıŏlu (thk.), Dâru'l-Mizân, İstanbul, 2005, XIV, 76-78. 
Bütün insanların bir ailenin fertleri olduklarına, "İşte biz, insan öldürmenin çok kötü bir iş olmasından dolayı İsrâiloğullarına şöyle emrettik: Canına kıyılan bir kimseye karşı (kisas), olmaksızın veya yeryüzünde fitne-fesadı önleme maksadına matuf bulunmaksızın her kim bir insanı öldürürse, tüm insanları öldürmüş gibi olur. Ama kim de bir insanın hayatını korur ve kurtarırsa bütün insanlara hayat bahşetmiş olur "20 âyetinin mealinde de işaret edilmektedir. Bu âyetten anlaşıldığ üzere insanlık ailesinin bir ferdine yapılan haksız bir muamele, ailenin bütün fertlerine yapılmış kabul edilirken, aynı şekilde bir insanın varlığının idamesi için gerekli olan şartların oluşturulması da adeta insanlık ailesinin ihya edilmiş olması sayılmaktadır. Nitekim başka âyetlerde de bir bütün olarak insanların Allah ile iletişim kurmada, ${ }^{21}$ yaratıllş hikmetinde, ${ }^{22}$ kendilerine üfürülen ruhta, ${ }^{23}$ bilgi edinme melekesine sahip olmada, ${ }^{24}$ saygınlıkta, ${ }^{25}$ vicdanl olmada $^{26}$ ve tabi'i haklarda $^{27}$ eşit olduklarının belirtilmesi bütün insanların aynı ailenin fertleri olduklarını ve dolayısıyla kardeş olduklarını göstermektedir.

İslâm'1n bir özeti mahiyetinde olan veda hutbesinde de İslâm kardeşliğinin yanında insan kardeşliğine de vurgu yapılmış ve etnik farklılıklardan dolayı bu kardeşliğin bozulmamasına: “Bütün insanlar Âdem'in çocuklarıdır. Âdem'de topraktan yaratılmıştır" 28 sözüyle de dikkat çekilmiştir. Hatta bununla da yetinilmeyip, "Soy-sop/kavmiyete çağıran, bunun için savaşan, bu yolda ölen bizden değildir" ${ }^{29}$ denilmekle bu hususta kesin bir tavır ortaya konulmuştur. ${ }^{30}$ Netice itibariyle Kur'an'da insan kardeşliğine dikkat çekilmekte ve bu kardeşliğin gereklerinin yerine getirilmesi talep edilmektedir.

\section{2. İslam Kardeşliği}

Kur'an-1 Kerim'de öncelikle Müslümanların kardeşliğinin tesisi amaçlanmaktadır. Kur'an'ın nazil olmasıyla oluşan bu kardeşlikte cahiliyedeki kan bağı yerine inanç esas alınmakta" ve "Müminler ancak kardeştirler" 32 cümlesiyle bu kardeşlik ifade edilmektedir. Bu âyette nesep kardeşliğini ifade eden ihve kelimesi, mecâzî olarak iman yoluyla gerçekleşen kardeşliği belirtmekte ve dolayısıyla Kur'an'ın çerçevesini belirlediği kardeşliğin nesep kardeşliğinden daha önemli olduğuna da işaret edilmektedir. Çünkü Kur'an ile oluşan kardeşlik aynı zamanda insan kardeşliğini de ihtiva etmektedir. ${ }^{33}$ Keza, miras hukukunda sadece soy kardeşliğinin değil de, soy kardeşliği ile beraber Kur'an ile oluşan kardeşliğin bir kriter olarak belirlenmesi, inançla oluşan kardeşliğin nesep kardeşliğinden ne denli üstün olduğunu da göstermektedir. ${ }^{34}$

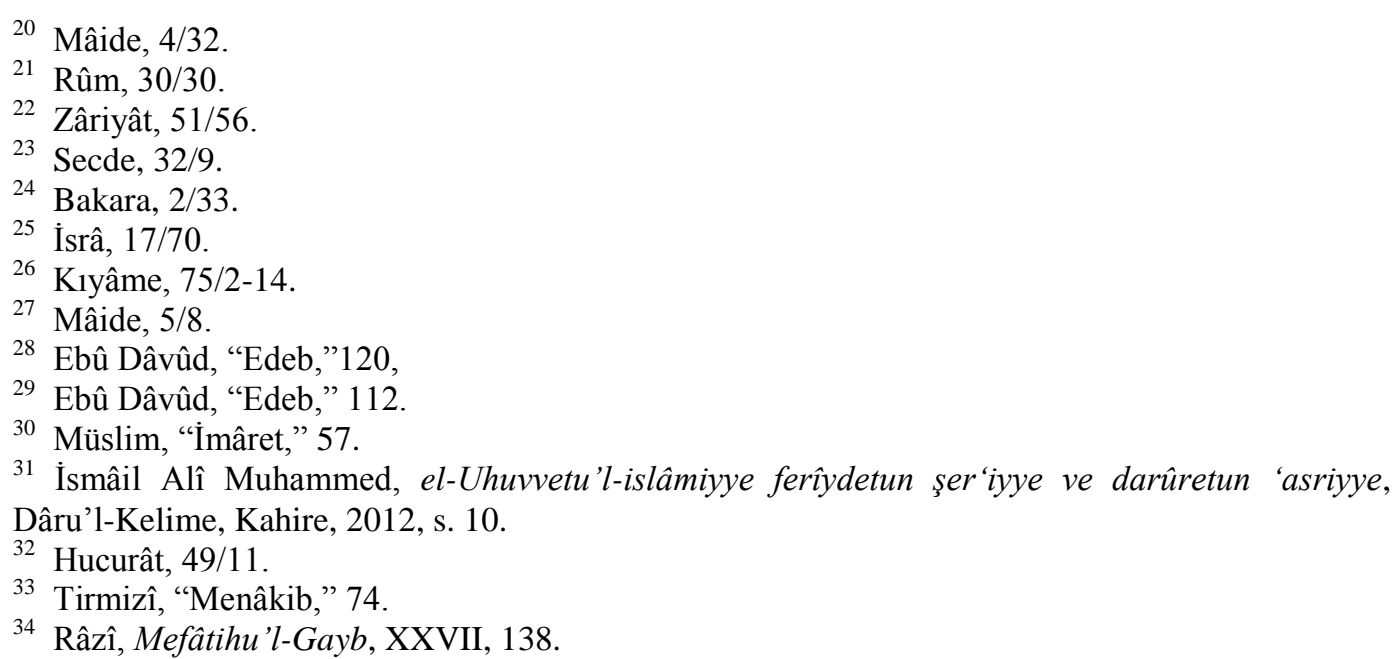


Mukâtil b. Süleyman'ın (ö.150/767) da belirttiği gibi “Hani siz bir vakitler savaş halindeydiniz, ama Allah kalplerinizi birbirinize ısındırdı ve O'nun lütfettiği nimet sayesinde kardeş oldunuz" ${ }^{35}$ âyeti inançla oluşan kardeşliği tasvir etmektedir. ${ }^{36} \mathrm{Bu}$ âyette özellikle Medine'de Evs ve Hazreç kabileleri arasında İslâm ile oluşan birlik ve beraberlik, nimet olarak isimlendirilerek Müslüman kardeşliğin ne kadar önemli ve aynı zamanda özel bir nimet olduğu belirtilmektedir. ${ }^{37}$ Ayrıca Kur'an'da İslâm kardeşliğinin oluşum şekli, “Bununla birlikte tevbe edip imana gelir, namazı kılar, zekâtı verirlerse sizin din kardeşiniz olurlar" "38 âyetinde açık bir şekilde ifade edilmektedir. Buna göre Müslüman olmadan önce Müslümanlara kötülük yapanların İslâm'1 kabul etmeleri halinde kardeş olacakları ${ }^{39}$ açık bir üslupla ortaya konulmaktadır. İslâm kardeşliğinin Allah, Peygamberler ve Kur'an başta olmak üzere kitaplara, meleklere, yeniden dirilmeye, hayrın ve şerrin Allah'tan olduğuna inanma esasları çerçevesinde gerçekleştiğini burada belirtmek gerekir. Böyle bir kardeşlik; düşünce, duygu ve eylemde şu'ûr birlikteliğinin oluşmasına vesile olmaktadır. Ancak kardeşliğin oluşması için Kur'an'da belirtilen ve insan fitratının da muktezası olan esasların dikkate alınması önem arz etmektedir.

\section{Kur'an Açısından Kardeşliğin Temelleri}

Sorumsuzluk ve duyarsızlıkların alışkanlık haline geldiği günümüzde ahlâkî ve insanî değerler ile toplumsal hayat arasında derin uçurumların meydana geldiğine şahit olmaktayız. Böyle bir durumun oluşumunda Kur'an'da belirtilen kardeşliğin ahlâkî ve insanî prensiplerinin genel anlamda davranışlara ve ilişkilere yansıtılamamasının etkin olduğunu düşünmekteyiz. Bundan dolayı kardeşlik anlayışının üzerine bina edildiği "Müslüman bir bireyin kendisi için sevdiği şeyleri kardeşi için de sevmedikçe hakiki bir mümin olamayacağını" 40 ifade eden hadis çerçevesinde yeniden düşünülmesi gerekmektedir. Özellikle bu hadiste geçen eh/ اخ kelimesinin sadece Müslümanları değil, bütün insanları kapsadığını ${ }^{41}$ burada zikretmek gerekmektedir. Ancak bu kuşatıcı bakış açısının sadece kendisi gibi düşünenleri değil, farklı olanları da kapsadığını göz önünde bulundurmak lazımdır. Kardeşliğin esası olabilecek birçok temel ilke bulunmakla birlikte bu çalışmamızda önemli gördüklerimiz üzerinde durmakla yetineceğiz.

\section{1. İnanç ve Düşünce Hürriyetinin Hâkim Olduğu Ortamı Oluşturmak}

Kur'an'da insanın özgür iradesiyle inancını ve hayat tarzını seçmesi temel bir ilke olarak ortaya konulmaktadır. Bu prensip, düşüncede, dolaşımda ve belli bir dini seçmede insanın özgür olmasıyla kendini gösterir. Çünkü insan hür olmakla insanî değerleri inkişaf eder ve kendine yakışmayan süflî şeylerden de uzak durur. Ancak hür olan kişi şahsiyetini zedeleyen eylemlerden kaçınmakla aynı zamanda kendi özgürlüğünü sınırlandırmaktadır. Çünkü belli bir sosyal gruba bağlı olan

\footnotetext{
35 Âl-i İmrân, 3/103.

${ }^{36}$ Mukâtil b. Süleymân, Tefsîru'l-Kebîr, I, 184.

${ }^{37}$ Taberî, Câmi 'u'l-Beyân, III, 380.

38 Tevbe, 9/11.

${ }^{39}$ Maturîdî, Te'vilâtu'l-Kur'ân, VI, 307.

${ }^{40}$ Müslim, "İman," 71.

${ }^{41}$ Muhammed Ebû Zehra, el-Mucteme 'u'l-İnsanî fi Zilli'l-İslâm, Dâru's-Suûdiyye, Riyâd, 1981, s. 167.
} 
kişiler, bu gruba mensubiyetleri nedeniyle karşılıklı olarak eylemlerini kayitlamaktadirlar. $^{42}$

Kur'an-1 Kerim, doğru inanç ve olumlu eylemler sergileme hususunda insanlara rehberlik yapmakta, ${ }^{43}$ doğruyu bulmak için çalışanları müjdelemekte ve yanlış yola sapmış olanları da uyarmaktadır. ${ }^{44}$ Bununla birlikte, "Dinde zorlama yoktur" 45 denilmekle, belli bir dini seçmede veya bir dindarlık anlayışını benimsemede baskının yapılmasının doğru olmadığı ifade edilmektedir. Çünkü dindarlık bir idraktir, kalbî bir iz'andır ve Allah'ın emirlerine teslim olmaktır ki tabiatıyla bunlarda zorlama söz konusu olamaz. ${ }^{46}$ Hakeza, İslam'da fikir ve inanç hürriyetinin bulunduğuna “(Ey Peygamber) insanlarl, İslâm'a hikmetle, güzel ögüt ve nasihatle davet et. Onlarla en güzel yöntemle mücadele et. Rabbin kimin hak yolda olduğunu ve kimin batıla saplandiğını bilir. Allah doğru yolda olanları bilir" ${ }^{\prime 47}$ âyetinin mealinde de işaret edilmektedir. Bu âyette farklı fikirler bask1 ve şiddetle değil, bilgi ve hikmetle mücadele edilmesinin gerekliliği üzerinde durulmaktadır. Muhammed el-Gazzâlî’nin (ö.1917-1996) de belirttiği gibi İslâm'da insanın belli bir inancı ve fikri kabullenmede baskıya maruz kalmaması ve her bireyin kendi inancının gereğini yaşaması temel bir ilke olarak benimsenmektedir. ${ }^{48}$ Dolayısıyla insana inanmanın veya inkârın dayatılması doğru değildir. Zira insanları fiziki olarak kendi egemenliğine almak mümkün olabilir. Ancak onların düşüncesine hükmetmek imkânsızdır. ${ }^{49}$ İslâm'ın önemli prensiplerinden olan ve kardeşliğin de önemli bir esası olan iyiliği emretmek, kötülükten sakındırmak ve hikmet ile insanları hakka davet etmek ilkelerini ihtiva eden söz konusu âyette de insanların düşüncelerine hükmetmek değil, onlara rehberlik yapmak, tebliğin temel bir ilkesi olarak benimsenmektedir.

Öbür taraftan insanları fikir ve düşünce özgürlüğünden mahrum bırakanların Kur'an'da tenkit edildikleri görülmektedir. ${ }^{50}$ Nakledildiğine göre eski Misır'da krallar, baş ilâhı temsil ediyorlardı ve Allah'ın vekilleri olarak kabul ediliyorlardı. Hz. Musa'nın dönemindeki Firavun da, kendisini en büyük Rab olarak ilan etmişti ve kendi izni olmadan Hz. Musa'ya vahyedilen inanç esaslarına inanmayı dahi yasaklamıştı. ${ }^{51}$ Hatta halkın Hz. Musa'dan etkilenmemesi için Hz. Musa'nın sihirbazlarla gizli anlaşma yaptığını ve amacının Mısırlıları, Mısır topraklarından çıkartıp buraya yerleşmek olduğunu iddia ediyordu. ${ }^{52}$

Ancak insanın kendi hayat tarzını belirlemede özgür olduğunu belirten âyeterin yanında insanın bu hususta herhangi bir etkisinin olmadığına işaret eden âyetler de söz konusudur. ${ }^{53}$ İnsanın inanç özgürlüğüne sahip olmadığını ifade eden söz

\footnotetext{
42 Bu konuda bk. Muhammed Ebû Zehra, el-Mucteme 'u'l-Insânî, s. 255-258.

43 İsrâ, $17 / 7$.

44 Sebe, 34/28; Fâtır, 35/ 25.

45 Bakara, 2/256.

${ }^{46}$ Ebû Zehra, Muhammed b. Ahmed b. Mustafa, Zehretu't-Tefâsîr, Dâru'l-Fikri'l-Arabî, Kahire, ts., II, 944.

47 Nahl, 16/125.

48 Muhammed el-Gazzâlî, el-Mucteme 'u'l-İnsanî, s. 265-266.

${ }^{49}$ Ahmet Aslan, İnsan Hakları ve İslam, s. 124, www.libertedownload.com. (Erişim: 1 Ocak 2018)

50 A'râf, 7/123-124.

51 Ahmet İnan, Insan haklarl ve Din, Çanakkale Üniversitesi Yayınları, Çanakkale, 2010, s. 40.

52 Ebû Hafs Ömer b. Alî ed-Dımaşkî İbn Adil, el-Lübâb fî 'Ulûmi'l-Kitâb, Dâru'l-Kutûbi'lİlmiyye, Beyrut, 1998, IX, 267-268.

53 A'râf, 7 /186; En‘âm, 6/125; Kases, 28/56; Rûm, 30/29; Müddessir, 74/31; Zümer, 39/37.
} 
konusu âyetler bir bütün olarak incelendiğinde bu âyetlerin, insanın özgür olup olamamasından ziyade, Allah'ın mutlak bir güç sahibi olduğunu ortaya koymakla ilgili olduğu görülecektir. Kâfirûn sûresinde açık bir şekilde kâfirlerin kendi inançlarını yaşama haklarının bulunduğunun belirtilmesi de bunu desteklemektedir. ${ }^{54}$ Ayrıca Kur'an'da inancının gereğini yaşamaya çalışanların engellenmesinin kinanmass ${ }^{55}$ ve Hz. Peygamber'in misyonunun insanlara doğruları iletmek ve bu hususlarda baskı kurmamak olduğunun ${ }^{56}$ ifade edilmesi de insanların inanç açısından özgür olduklarının başka bir kanıtıdır. Yusuf Karadâvî'nin insanın inanç ve düşüncede özgür olmasının, İslâm'ın temel değerlerinden biri olduğunu ve bu hususta herhangi bir baskının yapılmasının İslâmî değerlere ters düşeceğini belirtmesi de $^{57}$ bu çerçevede değerlendirilebilir. Hâsıl1, Kur'an'a göre insanlar din ve vicdan özgürlüğüne sahiptirler ve bu sebeple herhangi bir inancı ve ideolojiyi kabullenmeye zorlanmaları, kardeşliğin insanî ve ahlâkî temellerine aykırıdır.

\section{2 Adalete Riayet Etmek}

Kardeşliğin insanî ve ahlâkî temellerinden biri de insanların ırkına, rengine, inancına ve bölgesine bakılmaksızın hakkın ve hukukun egemen olduğuna tanıklık etmektir. Eşitlik manasını da ihtiva eden adalet, aynı zamanda bütün erdemlerin de kaynağıdır ve insanı, hatalardan koruyan hassas bir terazi gibidir. Öyle ki sağduyulu bir insan adalet kavramını duyduğunda ondan lezzet alır ve onun zıddı olan zulümden de nefret eder. ${ }^{58}$ Terim olarak adalet, herkesin hakkının verilmesini ifade ederken, onun zıddı olan zulüm hakk1 gasp etmektir. Bununla birlikte adalet, dürüst davranmayı ve hakka riâyet etmeyi de içermektedir. ${ }^{59}$ Ancak şunu ifade etmek gerekir ki, adalette herkesin işinin nev'ine göre hakkının verilmesi ve adalet ölçülerine göre kendisiyle muamele edilmesi temel bir prensip olarak kabul edilmektedir. Çünkü insanların sosyal konumu, yaptıkları işin kalitesi ve harcadıkları emek farklı olabileceği için her açıdan insanların eşit sayılması adalet kapsamında değerlendirilemez. ${ }^{60}$ Fakat adalet, eşitliğin gerçekleşmesi için gerekli ve kardeşliğin de önemli bir esasıdır.

Ancak adalet, sadece toplumsal hayat, kanun ve devletle ilgili fizikî ve görünür bir değer olmadığı için kardeşliği tam olarak gerçekleştiremez. Bireylerin iç dünyalarında da adalet duygusunun yerleşmesi önem arz etmektedir. Bu da ancak kişinin iç dünyasında kendisi için istediği şeyleri başkaları için de istemesiyle gerçekleşebilir. Aslında insanın zihin dünyasında gerçekleşen adalet duygusu pratik hayattaki adalet uygulanmasından daha değerlidir ${ }^{61}$ ve kardeşliğin oluşmasında da daha etkindir. Çünkü kanuna dayalı adaletin, insanın rengine,

\footnotetext{
${ }^{54}$ Konuyla ilgili bk., Kâfirûn, 109 /1-5.

55 'Alak, 96/9.

56 Ğâşiye, 88/21-22.

${ }^{57}$ Yûsuf Karadâvî, el-Klyemu'l-insâniyye fi'l-İslâm, s. 8, http://www.al-qaradawi.net. (Erişim: 12. Aralık 2017)

58 İsfahânî, Ebü'l-Kāsım Huseyin b. Muhammed b. el-Mufaddal er-Râgıb ez-Zerîyga ilâ Mekârîmi'ş-Şerî'a, Dâru İkra, Dımaşk, 2001, s. 247.

${ }^{59}$ İbn Âşûr, Muhammed Tahir b. Muhammed b. Muhammed et-Tunusî et-Tahrîr ve't-Tenvîr edDâru't-Tunusiyye, Tunus, 1984, XVI, 255.

60 Ömer b. Abdulazîz el-Kureyşî, Semahâtu'l-İslâm, Mektebetu'l-Edîb, Riyâd, 2006, s. 44.

${ }^{61}$ Muhammed Ebû Zehra, el-Mucteme 'u'l-insanî, s. 166.
} 
ırkına, dinine, bölgesine ve mezhebine bakılmaksızın gerçekleşmesi mümkündür. Ancak kalbî adaletin gerçekleşmesi zordur. ${ }^{62}$

Peygamberlerin gönderiliş amaçlarından birinin de yeryüzünde adaleti ikame etmek olduğunu, "Allah'a yemin olsun ki, biz peygamberleri mucizelerle gönderdik. Onlarla beraber kitabı indirdik ve insanlar arasında adaleti tesis edecek ölçüler belirledik" ${ }^{63}$ âyetinden de anlamak mümkündür. Ancak bu hususta dikkat edilmesi gereken şey, adaletin sadece kendi mezhep ve meşrebinden olan kişiler için değil, farklı din, mezhep ve meşreplere mensup olan herkes için söz konusu olmasıdır. Bu bakış açısına, "Hiç şüphesiz adaleti/doğruluğu, samimi ibadet ve itaati, akrabaya yardım etmeyi emreder" "64 âyetinde geçen adaletin mutlak olarak zikredilmesi de işaret etmektedir. Bu da insanlar arasında hüküm verilirken, asil aileler ile daha alt statülerde yer alan birey ve aileler arasında bir ayrımın yapılmasının adalet anlayışına ters olduğunu göstermektedir. Hatta, "Bir kavme olan kızgınlı̆̆ınız sizi adaletsizliğe itmesin. Adil davranın"65 âyetinde düşmanlara dahi adaletle muamele etmenin gerekliliğinin açık bir şekilde ifade edildiğini görmekteyiz.

Hz. Peygamber döneminde vuku bulan bir takım olaylar da kardeşliğin oluşması için adaletin önemine 1şı1k tutmaktadır. Usame b. Zeyd, Benî Mahzûn kabilesinden hırsızlık yapan asil bir aileye mensup bir kadının elinin kesilmemesi için aracılık yapmaya kalkıştığında, "Sizden önceki toplumların helak nedeni, onlardan asil olan birisi hırsızlık yaptığında eli kesilmezdi. Aşireti olmayan güçsüz birisi hırsızlık yaptığında ise eli kesilirdi. Allah'a andolsun ki, kızım Fatma dahi hırsızlık yaparsa onun elini keserim" ${ }^{\prime 66}$ şeklinde Hz. Peygamber'in tepkisiyle karşılaşır. Bu olay aynı zamanda adaletin uygulanmasında kadın ve erkek arasında bir ayrım yapılmasının da doğru olmadığını göstermektedir. Bu durum, "Erkek olsun kadın olsun, kim mümin olarak imanına yaraşır işler yaparsa biz ona dünyada mutlu bir hayat yaşatırız; ahirette ise onu güzel amellerine yaraşan mükâfatın en güzelliyle mükâfatlandırırız" ${ }^{, 67}$ âyetinde de net bir şekilde ortaya konulmaktadır.

Ayrıca kardeşliğin önemli bir esası olan adalet sadece maddi durumlara has bir değer değildir. Beşerî ilişkiler gibi durumlarda da adil davranmak gerekmektedir. Buna, Mekke'de yaşanmış şu olay örnek verilebilir: Mekke liderleri, Hz. Muhammed'den kendisiyle oturup konuşmaları için yakın bir zamana kadar kendilerine hizmetçi olanları yanından uzaklaştırmasını talep ederler. Hz. Muhammed de Mekke'nin bu etkin ve seçkin şahsiyetlerinin Müslüman olmalarını arzulamasından dolayı taleplerini olumlu karşılar. ${ }^{68}$ Fakat bu durumun akabinde Hz. Muhammed'i eleştiren âyetler nazil olur ve Mekke liderlerinin taleplerinin kabul edilmemesi hususunda uyarılır. ${ }^{69}$ Çünkü İslâm'da para ve makam değil, değerler esastır. Kureyş liderlerinin isteklerinin yerine getirilmemesi hususundaki talep de ${ }^{70}$ bu çerçevede değerlendirilebilir.

${ }^{62}$ Muhammed Ebû Zehra, el-Mucteme 'u'l-insanî, s. 168.

63 Hadîd, 57/25.

${ }^{64}$ Nahl, $16 / 90$

65 Mâide, 5/8.

66 Buhârî, "Hudûd," 12.

67 Nahl, 16/97.

${ }^{68}$ Taberî, Câmi ‘u’l-Beyân, V, 199.

69 En 'âm, 6/52.

70 Seyyid Kutup, Fî Zilâli'l-Kur'ân, Dâru'ş-Şurûk, Kahire, 2004, II, 1100. 
Adalet uygulamaları, kardeşliğin oluşması ve devam ettirmesi için temel bir ilke olmakla birlikte toplumun kendi varlığını devam etmesi için de önemli prensiptir. İbn Teymiyye'nin (ö.728/1328), "Adaletle hükmeden devlet kâfir de olsa devam eder. Zalim olan devlet Müslüman da olsa uzun ömürlü olmaz. Çünkü dünyanın hükümranlığı adalet ve küfürle devam edebilir. Fakat adaleti esas almayan İslâmî anlayış da olsa devam etmez"71 şeklinde adaletle ilgili tespitleri de bunu desteklemektedir. Zira tabiatıyla toplumda adalet söz konusu olduğunda düşünce, fikir ve üretimde gelişme olur, haksızlığın hüküm sürdügü toplumlarda ise yıkım gerçekleşir. Netice itibariyle adalet, Kur'an-1 Kerim'in temel değerlerinden biridir. Kardeşliğin ve toplumsal bütünlüğün oluşması ve devam etmesi için de önemli bir esastır.

\section{4. Haksızlığın Karşısında Olmak}

Adaletin zıddı olan zulmün her çeşidinin yasaklanması kardeşliğin oluşması ve devam etmesi için önemli ilkelerden biridir. Anlam olarak zulüm, karanlık ve bir şeyin olması gereken yerin dışına konulmasıdır. ${ }^{72}$ Buna göre Allah'a şirk koşmakta olduğu gibi kişinin kendisine ve başkalarına haksızlık yapması zülüm olarak değerlendirilmektedir. ${ }^{73}$ Kur'an' da Allah'1n, zalimlerin düşmanı olduğu, ${ }^{74}$ zalimleri sevmediği, ${ }^{75}$ zalimleri lanetlediği, ${ }^{76}$ onlan yok edeceği, ${ }^{77}$ haksılılı yapanlara yardım edilmeyeceği ${ }^{78}$ ve bu niteliklere sahip olan insanların cehenneme gideceklerinin $^{79}$ ifade edilmesi, İslâm'da her türlü zulmün ve haksızlığın yasaklandığını göstermektedir.

Adaletsizliğe uğramıș insanların desteklenmesinin zorunluluğu, "Maruz kaldıkları baskllardan kurtulmak için sizden yardım isterlerse onlara yardım ediniz" âyetinde ifade edilmektedir. Ancak bu âyetin muhtevası ister o günkü bedevîlerle ilgili olsun ister başkaları ile ilgili olsun haksızlığa maruz kalmış insanlara yardım etmeyi sadece âyetin nazil olduğu dönem ile sınırlandırmak doğru değildir. Kaldı ki Müslüman bir birey zalim bir duruma düşse dahi bu durumdan onun kurtarılması için mücadele etmek gerekmektedir. Bu hususta hadis kitaplarında şu bilgiler nakledilmektedir: "Müslüman kardeşin zalim de olsa mazlum da olsa ona yardım et. Sahâbîlerden birinin, "Ey Allah'ın resulü Müslüman kardeşimiz mazlum olduğunda ona yardım etmeyi anladım, fakat zalim olduğunda ona nasıl yardım edilebilir? şeklinde sorduğu bir soru üzerine Hz. Peygamber, zalim olan kardeşinizi haksızlık yapmaktan alıkoymak, ona yardım etmek anlamına gelir" diye söyler. ${ }^{81} \mathrm{Bu}$ hadis aynı zamanda Müslüman olmakla karşılıklı hakların ve sorumlulukların da oluştuğuna işaret etmektedir. Müslümanlar arası ilişki nev'ine, "Müslümanların kanları birbirine denktir ve Müslüman olmayanlara karşı tek bir

71 İbn Teymiyye, Ebu'l-Abbâs Takıyyüddîn Ahmed b. Abdilhalîm b. Mecdiddîn Abdisselâm elHarrânî, Mecmu'u'l-Fetâvâ Mektebetü'l-Ubeykân, Riyâd, 1997, XXVIII, 146.

72 İbn Fâris, Ebu'l-Hüseyin Ahmed b. Fâris b. Zekeriyyâ, Mu'cemu Makâyîsu'l-Luğa, thk. Muhammed Murîb ve Fatime Muhammed Aslan, Dâru İhyâi't-Turâsi'l-Arabî, Beyrut, 2001, 617.

73 İsfahânî, el-Mufredât, s. 537-538.

74 Bakara, 2/193.

75 Âl-i İmrân, 3/57.

76 Hûd, 11/18.

77 İbrahim, 14/13.

78 Bakara, 2/270.

79 İnsan, 76/31.

80 Enfâl, 8 /72.

81 Buharî, "Mezâlim,” 6; Tirmizî, "Fiten,” 68. 
el gibidirler. Üstelik konum olarak en alt düzeyde olan bir Müslümanın verdiği eman (güven), diğer Müslümanları bağlar" ${ }^{\circ 2}$ manasındaki hadiste Müslümanların birbiriyle ilişkilerinin niteliği ortaya konulmaktadır.

Kur'an'da haksızlığa maruz kalan kişilerin dinine ve kimliğine bakılmaksızın haklarının savunulması yönünde birçok âyet ${ }^{83}$ bulunmaktadır. Nisâ sûresinde bu hususta şöyle denilmektedir: "Ey müminler! Medine'ye hicret edemedikleri için Mekke'de baskı ve zulme maruz kalan çaresiz erkekler, kadınlar ve çocuklar, "ya Rab! Bizi bu zalim müşriklerin hüküm sürdüğ̈̈ Mekke'de yaşamaktan kurtar. Lütuf ve merhametinle bize sahip çıkıp yardım eli uzatacak birilerini gönder" diye feryat edip dururken, eli silah tutan siz müminlerin Allah yolunda ve ayn zamanda o çaresiz insanları zulümden kurtarma uğrunda kafirlerle savaşmaması olacak şey mi hiç?!"84 Özellikle bu âyette geçen "mustaz'af" kelimesinin " $f i$ sebilillah" terkibi üzerine atfedilmesi, ezilen bireyleri kurtarmak için mücadele etmenin, adeta Allah yolunda savaşmak gibi önemli olduğu mesajını vermektedir. ${ }^{85}$ Hassaten yetişkinlerle birlikte çocuklardan bahsedilmesi Mekke'de Müslümanlara uygulanan baskının hangi boyutlara ulaştığını göstermektedir. ${ }^{86}$ Ancak şunun bilinmesinde de fayda vardır ki, insanlara yardımcı olmak, onları savunmak için savaşa başvurmak, söz konusu âyetin indiği bağlamla sinırlı değildir. İbn Atiyye'nin (ö.541/1147) de bu hususa dikkat çektiği üzere yukarıdaki âyet kıyamete kadar haksızlığa maruz kalacak olan Müslümanları, esirleri ve müşrikleri kurtarmaya yönelik başvurulacak bütün savaşları kapsamaktadır. ${ }^{87}$

Ayrıca Kur'an'da yoksulların ve ihtiyaç sahiplerinin desteklenmesi de bir hak olarak belirtilmektedir. Bu hususta insanları teşvik etmeyenlerin, Mâ'ûn sûresinde geçen "İste o, yetimi horlar, itip kakar; fakir-fukarayı duyurmaz, bu hususta bir başkasını teşvike bile yanaşmaz" ${ }^{\prime 28}$ âyetiyle tenkit edildikleri görülmektedir. Öyle ki temel ihtiyaçlardan komşusunu mahrum edenler, namaz dahi kılsalar Allah'ın azabına maruz kalacaklardır. ${ }^{89}$ Hulasa, haksızlığa karşı mücadele etmek, hakkın ve adaletin gerçekleşmesi için çalışmak, kardeşliğin temel dayanaklarından biridir.

\section{5. Merhametle Muamele Etmek}

Söz ve davranışlarda insanlara karşı merhametli olmak, kardeşliğin temellerinden biridir. Merhamet anlam olarak, acı hissetmek, şefkat etmek, bağışlamak ve

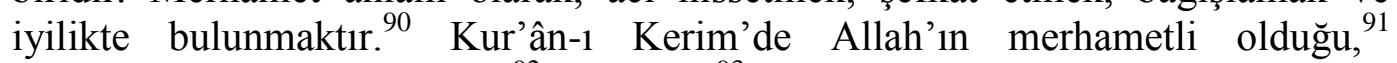
merhametinin sinırsız olduğu, ${ }^{92}$ Kur'ân' ${ }^{93}$ ve Hz. Muhammed'in de insanlar için rahmet oldukları" belirtilmektedir. "Merhametin olduğu yerde güzellik olur ve

\footnotetext{
82 Ebû Dâvûd, "Cihâd," 147.

${ }^{83}$ Enfâl, 8 /26; Şu'arâ, /227; Nûh 71 /28; Nisâ 4/10; Yûnus 10 /44.

${ }^{84}$ Nisâ, 4/75.

85 Kurtubî, el-Câmi 'li-Aĥhâmi’l-Ķur’ân, VI, 460.

86 Âlûsî, Ebü's-Senâ Şihâbüddîn Mahmûd b. Abdillâh b. Mahmûd el-Huseynî, Rûhu'l-Me 'Ân̂ fî Tefsîri'l-Kur'an ve's-Seb 'I'l-Mesânî, Dâru'r-Risâle, Beyrut, 2015, VII, 140-141.

87 İbn Atiyye, el-Muharreru'l-Vecîz, II, 78-79.

88 Ma'ûn, 107/2-7.

${ }^{89}$ Ebü't-Tayyib Muhammed Siddîk Bahâdır Han b. Hasan b. Alî el-Kannevcî, Fethu'l-Beyân fî Mekâsidi'l-Kur'an, Abdullah İbrahim (thk.), el-Mektebetu'l-Asriyye, Beyrut, 1992, XV, 404.

90 İbn Manzûr, Lisânu'l-Arab, V, 173.

91 En'âm, 6/54.

92 En'âm, 6/147.

93 Neml, 22/77; Yûnus, 10/57; İsrâ, 17/82.

94 Enbiyâ, 21/107.
} 
olmadiğ yerlerde olumsuzluklar olur" 95 ve "Yerdeki canlılara iyilikte bulununki Allah'ta size merhamet etsin" 96 gibi hadislerde merhametli olmanın önemine dikkat çekilmektedir. Çünkü iyilikte bulunmak insanların acılarını hissetmek, 1zdıraplarını dindirmek ve iniltilerini duymak anlamına gelmektedir. ${ }^{97}$

Tevbe sûresi dışında bütün sûrelerin başında bulunan besmelede Allah'ın Rahmân ve Rahîm isimlerinin yer alması, İslâm anlayışının rahmet üzerine bina edildiğine işaret etmektedir. Özellikle Rahmân sıfatından sonra aynı kökten olan Rahîm'in getirilmesi merhametli olmanın önemine dikkat çekmek içindir. ${ }^{98}$ Dilsel olarak ilâhî merhametin sonsuzluğunu ifade eden besmelenin Kur'an'ın hemen başında yer alması, Kur'anî değerlerin temelinde bütün canlılara şefkatin esas alındığına hemen işin başında ifade etmeye yöneliktir. Bu durum, "Ben dilediğimi azabıma çarptırma gücüne sahibim. Rahmet ve şefkatim ise her şeyi kuşatmıştır" 99 âyetinde de açık bir şekilde ifade edilmektedir.

Ayrıca Kur'an'da iyilikte bulunmanın, "Onların mallarında mahrum ve muhtaç olanların hakları vardır" "100 âyetinde açık bir şekilde ifade edildiğini görmekteyiz. Taberî (ö.310/923), bu âyette söz konusu olan hakkın, zekât olduğunu söyleyen âlimlerin olduğu gibi bunun zekât dışında sadaka ve diğer malî katkılar olduğunu iddia eden âlimlerin de bulunduğunu söylemektedir. ${ }^{101}$ Ancak İbn Atiyye, zekâtın Medine'de farz kılındığı ve bundan dolayı bu âyette bahsedilen hakkın zekât dışında diğer malî katkılar olduğunu düşünenlerin yorumunun âyetin bağlamıyla daha uygun olduğunu iddia etmektedir. ${ }^{102}$ Diğer taraftan söz konusu âyette geçen "sâil" kelimesinin yardım talebinde bulunan yoksul kişiler ve "mahrum" kelimesinin ise ganimetten pay almayan fakir kişiler ${ }^{103}$ olduğunu söyleyenlerin yanında; "sâil" kelimesinin ihtiyaçlarını temin etmek için dilenen ve "mahrum" kelimesinin ekini telef olmuş, hayvanları yavru doğurmayan ve ağaçları meyve tutmayan kişi olarak yorumlayan tefsirciler de olmuştur. ${ }^{104}$ Kur'an'da sekiz grup olarak zikredilen insanlara yapılan yardımların $\mathrm{da}^{105}$ insanlara merhamet kapsamında değerlendirildiğini burada zikretmek gerekir. Velhasıl, ister toplumsal ve ister bireysel olsun sıkıntı çeken ve zorda olanların desteklenmesi ve gereken yardımların yapılması, kardeşliğin esaslarından biridir. Bu esastan yoksun bir kardeşliğin varlığını devam etmesi zor olacaktır.

\section{6. İnsanın Onurunu Muhafaza ve Müdafaa Etmek}

Kardeşliğin temelini oluşturan insanî ve ahlâkî ilkelerden birinin de insanın onurunu korumak olduğunu söylemek mümkündür. Çünkü insan yapı olarak en güzel şekilde yaratılmış, onurlu ve değerli bir varlıktır. Ancak insanın saygın oluşu sadece onun fizyolojik yapısı ve şekliyle ilgili değildir. İnsanın sahip olduğu

\footnotetext{
95 Müslim, "Birr," 78; Ebû Dâvûd, "Edeb,” 10.

96 Tirmizî, Birr, 16; Ebû Dâvûd, Edeb, 58.

97 Kemal Sayar, Merhamet, 8. bs., Timaş Yayınları, İstanbul, 2013, s. 71.

98 Rağıb Sercânî, el-Klyem ve'l-Ahlâk fî'l-Hadâreti'l-İslâmiyye, s. 83. www.raoulallah.net. (Erişim: 150 1, 2017)

99 A'râf, 7/156.

100 el-Meâric, 70/24-25.

101 Taberî, Câmi 'u'l-Beyân, XII, 236-237.

102 İbn Atiyye, el-Muharreru'l-Vecîz, III, 368.

${ }^{103}$ Mukâtil b. Süleymân, Tefsîr-i Kebîr, III, 399.

${ }^{104}$ Mâtürîdî, Te 'vilâtu'l-Kur'ân, XVI, 105.

105 Tevbe, $9 / 60$.
} 
akıl ve iradeyle de ilgisi vardır. İnsana tevdi edilen hilafet ${ }^{106}$ misyonu da onun bu özelliklerinden kaynaklanmakta ve bu yönüyle insanın onurlu ve şahsiyetli bir varlık olduğuna da işaret edilmektedir. İnsanın onurlu bir varlık olduğu, "Biz Âdem çocuklarını saygın kıldık. Onları deniz ve karada taşıdık. Onlara güzel rızıklar verdik ve onları yarattıklarımızın birçoğuna üstün kıldık"107 âyetinde de açık bir şekilde ifade edilmektedir. Zemahşerî’nin (ö. 538/1144) belirttiğine göre söz konusu insanın saygınlığı ve onuru (kerameti), insanın akletmesi, konuşabilmesi, eşyayı birbirinden ayırt etmesi, yazı yazma kabiliyeti, dünya ve ahiret işlerini birbirinden ayırabilecek bir idrake sahip olmasıdır. ${ }^{108}$

İnsanın, duygu ve düşüncelerini beyan etme özelliğine sahip olması, denizde ve karada taşınabilme potansiyeli, en güzel yiyeceklerin kendisine sunulması insanın şahsiyetli olduğunu göstermektedir. ${ }^{109}$ Ancak insanın saygınlığı, sadece onun bu özellikleriyle sınırlı değildir. İnsanın sorumluluk sahibi olması da onun onurlu bir varlık olduğunun bir kanıtıdır. ${ }^{110}$ Ayrıca, insanın bilgi sahibi olabilme istidadı, ${ }^{111}$ meleklerin kendisine saygı göstermesi, ${ }^{112}$ insanın şekil olarak diğer varlıklardan daha güzel olması ${ }^{113}$ gibi nitelikler de insanın saygınlığının ifade biçimleridir. Öyle ki ölümünden sonra dahi insanın saygınlığının korunmasının talep edildiğine şahit olmaktayız. Hz. Ayşe'den nakledilen bir rivayette şöyle denilmektedir: "İnsan diri iken kemiğinin kırılması nasıl ki onun onuruna yakışmıyorsa ölümünden sonra da durum böyledir." ${ }^{114}$ Hakeza, insana hitap edildiğinde güzel bir üslubun kullanılması, kibar ve nazik davranılmasının istenmesi de insanın erdemli bir varlık olduğunu göstermektedir. ${ }^{115}$ Bütün bu bilgiler insan kardeşliğinin oluşması ve devam etmesi, insan onurunun korunmasına bağlı olduğunu göstermektedir. Bu nedenle onuru zedelenmiş bir insandan kardeşliğin beklenmesi gerçekçi bir yaklaşım olamaz.

Veda hutbesinde Hz. Peygamber, insan onurunun korunmasını gündeme taşımakla kalmamış, onun muhafaza edilmesini de talep etmiştir. ${ }^{116}$ Kardeşliği pekiştiren bu durum bazı hadislerde, Müslüman bir bireyin onurunun zedelendiği bir ortamda onu desteklemeyen Müslümanın zelil olacağı, ${ }^{117}$ Müslümanın onurunu korumak için mücadele eden ve onun olmadığı bir ortamda da onu müdafaa eden kişinin cehennem azabından korunacağ $1{ }^{118}$ belirtilmektedir.

İslâm'ın da önceliğgi bir bütün olarak insanın saygınlığını ve şahsiyetini korumaktır. Aslında insan olmak bu durum için yeterli bir gerekçe sayılabilir.

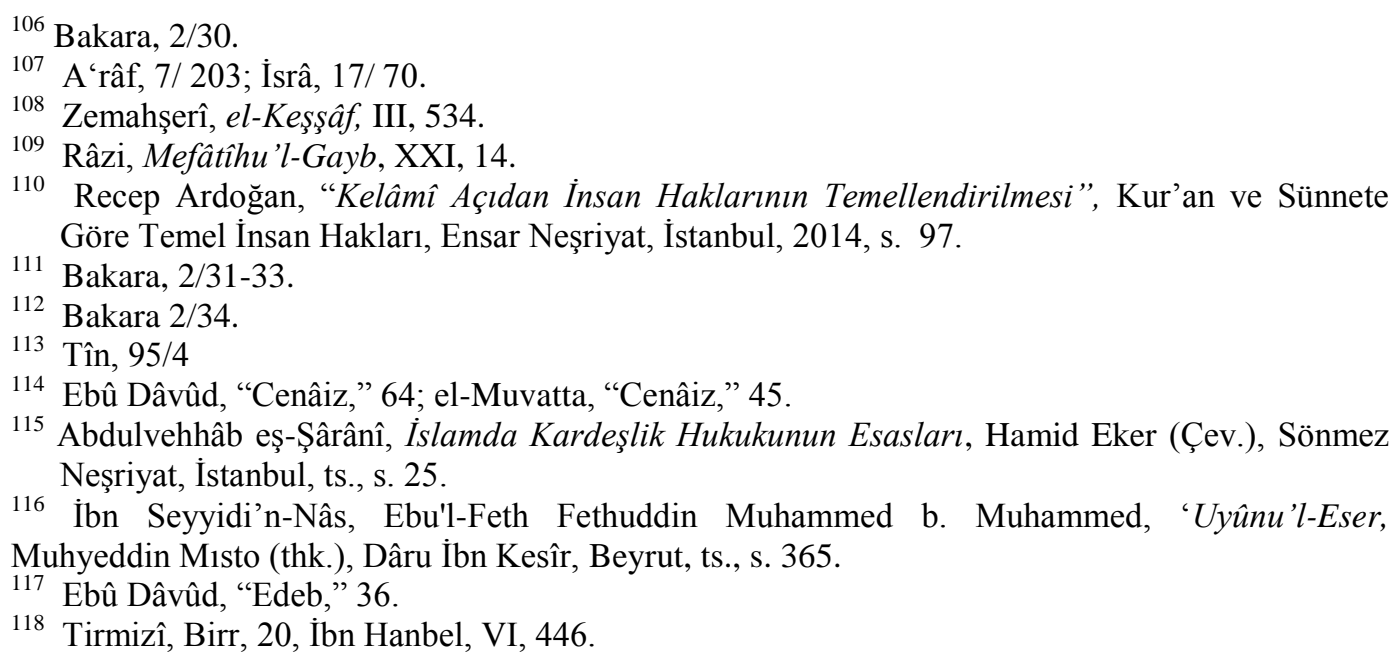


İnsanla alay edilmesi, şahsiyetini küçük düşürücü isimlerle hitap edilmesi, 119 küfür ve hakarette bulunulması, ${ }^{120}$ giybet, haset, iftira, işkence ve baskı gibi durumların yasaklanması da insan onurunu muhafaza etmeye ve dolayısıyla kardeşliği korumaya yönelik bir kısım tedbirlerdir. Hz. Peygamber döneminde yaşanmış bazı durumlar insan saygınlığının sadece insan yaşamıyla sınırlı olmadığını, öldükten sonra da saygınlığının devam ettiğini göstermektedir. Bir gün Hz. Peygamber sahâbîleriyle otururken yanlarından bir cenaze geçer. Kendisi ayağa kalkınca sahâbîler de ayağa kalkarlar. Fakat sahâbîler, cenazenin Yahudi birisine ait olduğunu da söyleyerek adeta Yahudi birine bu saygının gösterilmesinin doğru olmadığını ima ederler. Bunun üzerine Hz. Peygamber şöyle der: "Bir cenazeyi gördüğünüzde ayağa kalkın. Çünkü ölüm korkunç bir durumdur" ${ }^{121} \mathrm{Bu}$ olaydan da anlaşıldığı üzere insanın inancı farklı da olsa insan saygın bir varlıktır. Hz. Muhammed'in peygamber olmadan önce ve peygamber olduktan sonra içinde yer aldığı bütün oluşumlardaki maksadının, insanların hakkını ve onurunu korumak olduğunu ${ }^{122}$ burada zikretmek gerekmektedir. Sonuç itibariyle insanın onurunu korumak ve şahsiyetini zedeleyebilen bütün söz ve davranışlardan kaçınmak ve bu yönde gereken tedbirleri almak, kardeşliğin önemli insanî ve ahlâkî temellerindendir.

\section{7. Beşerî ve Sosyal İlişkilerde Dürüstlüğü Benimsemek}

Beşerî ilişkilerde dürüstlügün esas alınması, insanlar arası ilişkilerde güvenin oluşmasına vesile olmakta ve dolayısıyla kardeşlik ilişkilerini de pekiştirmektedir. Arapçada sıdk kelimesiyle ifade edilen dürüstlük, söylenen sözün veya herhangi bir şeyin kuvvetli olması anlamındadır. Yalanın zıddı olan dürüstlük haddizatında güçlü olduğu için bu isim ile anılmaktadır. Arapçada dürüstlükten ayrılmayan erkek الصِدِيقِ dürüstlükle tanınan kadın evlilik akdinden sonra kadına verilen Mehir صَدَاقٌ kelimesiyle ifade edilmektedir. ${ }^{123}$ Özellikle Kur'an'da mehir'in sadâk ile isimlendirilmesi, evlilik akdine bağlı kalındığına işaret etmektedir. $^{124}$

Kur'an'da s-d-k harflerinden türeyen dil formları, sözde dürüstlük, ${ }^{125}$ tasdik etmek, ${ }^{126}$ sadaka vermek, mali katkıda bulunmak, ${ }^{127}$ eylemde dürüst olmak ${ }^{128}$ ve dürüst olan erkek ve bayanlar anlamında kullanılmaktadır. ${ }^{129}$ Özellikle Kur'an'ın "Allah'ın kelâmı dürüstlük ve adalet olarak tamamlanmıştır"130 âyetinde, sıdk/dürüstlük ve adaletle nitelendirilmesi, Kur'anî değerler içinde dürüstlüğün ve adaletin ne kadar önemli olduğunu ortaya koymaktadır. Bu âyette her ne kadar tekil olan "kelime" zikredilse de, mecâzi olarak kelâm yani Kur'an-1 Kerim

\footnotetext{
119 Hucurât, $49 / 11$

120 Buhârî, İman, 36; Müslim, “İmân,” 116; Tirmizî, "Birr,” 51; İbn Mâce, "Fiten,” 4.

121 Müslim, "Cenâiz," 78;

122 Mustafa Önder, "Kur'an ve Sünnette İnsan Onuruna Eğitim Açısından Yaklaşım”, Amasya

Üniversitesi Illâhiyat Fakültesi Dergisi Cilt: 2, sy: 4, s. 47.

123 İbn Fâris, Mu'cemu Makâyîsi'l-Luğa, s. 565.

124 İbn Âşûr, et-Tahrîr ve't-Tenvîr, II, 230.

125 Yûsuf,12/26; Neml, 16/28; Mâide, 5/113; Bakara, 2/177.

126 Tahrîm, 66/12; Vâki'a, 56/57; Kases, 28/34.

127 Mâide, 5/45; Bakara, 2/280; Yûsuf, 12/88; Nisâ, 4/92. Ayrıca bk. Bakara, 2/199-281;

Mucâdile, 85/12; Tevbe, 9/60-85-103 âyetlere de bak1labilir.

${ }_{128}$ Meryem, 19/54; Ğâfir, 40/28; En'âm, 6/146; Hucurât, 49/15; Ahzâb, 33/35.

129 Yûsuf, 12/46; Hadîd, 57/19; Nisâ, 4/64.

130 En‘âm, 6/115.
} 
kastedilmektedir. Araplar, "Bu filan kişinin kelimesidir" ifadesiyle kasidenin bir bütün olarak bir şahsa ait olduğunu ifade ederler. Buna göre bu âyette parça (cüz) olan kelime, bütün olan (kül) kelâmın yerine kullanılmaktadır. ${ }^{131}$ Kur'an'da dürüstlüğe verilen bu önemden olmalıdır ki hakkı, adaleti ve ahlâkî değerleri öğretmek için gönderilen peygamberler, ${ }^{132}$ salih insanlar, ${ }^{133}$ inancinı ve değerlerini yaşamak için hicret edenler ${ }^{134}$ ve bir bütün olarak Müslümanlar sıdk vasfiyla nitelendirilmektedirler. ${ }^{135}$

Hadislerde de dürüstlüğün önemi üzerinde durulmakta ve dürüstlüğün insanı cennete götüreceği belirtilmektedir. Bu durum bir hadiste şöyle belirtilmektedir: "Dürüstlükten (sıdk) ayrllmayın. Zira dürüstlük sizi iyiliğe (birr), iyilik de sizi cennete götürür. Kişi sürekli dürüst olur ve dürüstlüğ̈̈n peşinde olursa Allah katında dürüst olanlardan (sıddîk) yazılır. Yalandan kaçının, zira yalan sizi kötülüklere (fucûr) götürür. Kişi sürekli yalan söyler, yalanın peşinde olursa Allah katında yalancılardan (kezzâb) olduğu yazılır. "136 Bu hadiste ifade edilenler bir ahlâkî ilke olarak dürüstlüğün ne denli önemli olduğunu göstermektedir.

Hâsılı kelâm, söz ve eylemlerde dürüstlüğün prensip haline getirilmesi, kardeşliğin oluşumu ve devamı için önemlidir. Dürüst bir birey olmak aynı zamanda Kur'anî değerlerin temelini oluşturan ilkelerinden birini yaşamak anlamına gelmektedir. Bundan dolayı beşerî ilişkilerde ve sosyal hayatta dürüst davranmak, kardeşliğin önemli temellerinden sayılmaktadır.

\section{8.Toplumsal Sorunlarda Çözüm Odaklı Yaklaşım Sergilemek}

Kardeşliğin önemli esaslarından biri de sorunlar vuku bulduğunda çözüm odaklı düşünmektir. Çünkü insanlar, şekil, ahlâk, renk, dil, yetenek, idrak ve düşünce açısından farklıdırlar ${ }^{137}$ ve bundan dolayı zaman zaman aralarında sorunlar meydana gelebilir. İnsanın bu yapısını bilen Yüce Allah, ${ }^{138}$ insanlar arasında ihtilaflar vaki olduğunda çözüm yollarının neler olabileceğini onlara bildirmekte ve bu durum sulh kavramı ile ifade edilmektedir. Sulh, insanlar arasında vaki olan uzaklaşmayı ortadan kaldırarak ${ }^{139}$ insanların ilişkisini normale çevirmektir.

Toplumların çöküşünün elbette birçok nedeni olabilir. Ancak bu hususta dâhili düşmanlıklar ve bölünmeler en etkin olanlarıdır. Bundan olmalıdır ki Müslüman gruplar birbiriyle çatıştığında aralarındaki sorunların normal yollarla çözülmesi ve haksızlığa uğramış olan grubun desteklenmesi gerekmektedir. $\mathrm{Bu}$ da bu durumlarda taraf değil, barışı destekleyen üçüncü taraf olmayı iktiza etmektedir ve yapılan barışın da hakka ve adalete dayanması lazımdır. ${ }^{140}$ Ancak önemli olan ihtilaf anında birey ve grupların birbirini tekfir veya tadlîl etmemeleridir. Çünkü Kur'an'da birbiriyle savaşanlar mümin kardeşler olarak ifade edilmektedir. ${ }^{141}$ Burada önemli olan zedelenen kardeşlik duygularının tekrar canlanmasıdır.

131 Taberî, Câmi 'u'l-Beyân, 12: 62.

132 Meryem, 19/41-49-58; Yûsuf, 12/51; A'râf, 7/ 104-105; Ahzâb, 33/22.

133 Nisâ, 4/ 69;

134 Haşr, 59/8.

135 Ahzâb, 33/ 15-23-24.

136 Buhârî, "Edeb," 69; Müslim, “Birr,” 103, 104.

137 Rûm, 30/22.

138 Mülk, 67/14.

139 İsfahânî, el-Müfredât, s. 489.

140 Hucurât, 49/9.

141 Hucurât, 49/10. 
Bundan dolayı tarafların birbirlerini affetmesi ${ }^{142}$ ve olumsuz bir dil kullanmaktan kaçınmaları $^{143}$ önem arz etmektedir. Aslında Müslüman bir birey inancının gereği olarak da lanet okumaz, insanların şahsiyetini rencide etmez, kötü ve çirkin bir dil kullanmaz. ${ }^{144}$ Netice itibariyle toplumdaki ihtilafların ortadan kaldırılması ve kardeşliğin oluşturulabilmesi için kardeşliğin esası olan insanî ve ahlâkî değerlerin işlevsel olması gerekmektedir. Bu esasa dayalı kardeşlik, aynı zamanda farklı ırk ve mezheplere mensup insanların ilişsilerini de güçlendirecektir.

\section{9. İyinin Yanında, Kötünün Karşısında Olmak}

İyi davranışları desteklemek ve kötü olanlardan sakınmak kardeşliğin temel referanslarından biridir. Ancak şunun belirtilmesi gerekir ki, kardeşlik ilişkilerinin geliştirilmesinde, ilâhî vahiy, akl-1 selîm, insan fitratına aykırı olmayan bakış açıları ve ahlâkî değerler önemli rol oynamaktadırlar. Kur'an'da bahsedilen ma'rûf' un ${ }^{145}$ gereğinin yapılması ve münkerden ${ }^{146}$ de kaçınılmasının emredilmesi de yukarıda mevzubahis olan durumlarla ilgilidir. Aslında ma'rûf kelimesi de, toplumda yaşanmakta olan, Müslümanlar tarafından hoş karşılanan ve çirkin sayılmayan değerleri ifade etmektedir. ${ }^{147}$ Başka bir deyimle "maruf, gerçek inanıştan doğup onunla ahenk arz eden eylemleri, münker de Allah'ın emirleri ile çatışacak mahiyetteki fiilleri ifade etmektedir. ${ }^{148}$ Ma'ruf ve münker kavramları, "Sizden hayra davet eden bir cemaat olsun. Onlar marufu emreder ve münkerden de nehiy ederler. Bu niteliklere sahip olanlar başarıl elde etmişlerdi" 149 âyetinde görüldüğü gibi imana takdim edilmişlerdir. ${ }^{150}$ Böyle bir üslubun kullanılması, toplumsal hayat için iyiliğin yanında ve kötülügün karşısında olmanın ne kadar önemli olduğunu ortaya koymaktadır. Ancak bunların imandan daha öncelikli oldukları sonucuna varmak da doğru değildir. ${ }^{151}$

Toplumda iyiliğin yaygınlaştırılması ve kötülükten de toplumun arındırılması hususunda "Mümin erkekler ve mümin kadınlar birbirlerinin yardımcısıdırlar. Onlar marufun hâkim ve kötülüğ̈̈n mahkûm olması için uğraşırlar"152 âyetinde de belirtildiği üzere kadınlar ile erkekler aynı sorumluluğu taşımaktadırlar. Ancak iyiliğin emredilmesi ve kötülüğün nehyedilmesi edilmesi hikmetle, yumuşak bir dil kullanmakla ve en etkili yöntemi benimsemekle gerçekleşmesi gerekmektedir. ${ }^{153}$ Netice itibariyle toplumun birliğinin sağlanmasının, erdemli bir toplumun, ekonomik ve sosyal açıdan toplumsal güvenin oluşturulmasının ve toplumsal düzenin tesis edilmesinin, kardeşliğin esaslarından biri olduğunu düşünmekteyiz.

\footnotetext{
142 A'râf, 7/199; Bakara, 2/178.

143 Hucurât, 49/12.

144 Tirmizî, Birr, 48-71.

145 Âl-i İmrân 3/104-110; A'râf, 7/157; Hac/41; Lokman, 31/17.

146 Münker, aklın ve bozulmamış insan fitratının onaylamadığı şeylerin ortak adıdır. Bu konuda bk. İbn Âşûr, et-Tahrîr ve't-Tenvîr V, 134-136.

147 Bu hususta bk. Taberî, Câmiu'l-Beyan III, 385.

148 Detaylı bilgi için bk.Toshiliko İzitsu, Kur'an'da Dini ve Ahlâkî kavramlar, Pınar Yayınları, İstanbul, ts., s. 326.

149 Âl-i İmrân, 3/110.

150 Râzî, Mefâtihu'l-Gayb, VII, 157.

151 İbn Âşûr, et-Tehrîr ve't-Tenvîr IV, 36.

152 Tevbe, 9/71.

153 Nahl, $16 / 125$.
} 


\section{10. Hoşgörü ve Saygı Çerçeveli Bir Dil ve Üslup Kullanmak}

Fıtrat gereği toplu halde yaşayan insanların her bir ferdinin inancı, kişiliği, yaşama biçimi ve hayata bakışı farklı olabilir. İnsanların, birbirlerinin bu farklı yönlerini olduğu gibi kabul etmelerine hoşgörü denilmektedir ve anlam olarak da taassubun zıddıdır. ${ }^{154}$ Diğer taraftan beşerî ilişkilerde güzel ve aynı zamanda muhataba değer atfeden bir dilin kullanılması, bireylerin birbirleri üzerindeki bir hakkıdır ve bu hak, Müslüman olsun-olmasın herkes için söz konusudur. Kur'an'da Hz. Musa ve Hz. Harun'un Firavun'a vahyi tebliğ etmek için gönderildiklerinde ona karşı yumuşak davranılması ve saygı dilinin kullanılması istenmektedir. $^{155}$

Kur'an-1 Kerim'de etkileyici üslup; güzel söz (kavl-i hasen), uygun ve olumlu söz (kavl-i maruf), ${ }^{156}$ dengeli söz (kavl-i adl), (sağlam ve doğru söz (kavl-i sedid), ${ }^{157}$ hoş söz (kavl-i tayyib), yumuşak ve faydalı söz (kavl-i leyyin), ${ }^{158}$ saygilı söz (kavl-i kerim), ${ }^{159}$ açık söz (kavl-i beliğ $)^{160}$ ve kolaylaştırıcı söz (kavl-i meysur), ${ }^{161}$ gibi vasıflarla nitelendirilmektedir. Buna mukabil iletişimi olumsuz etkileyen dil, kötü söz (kavl-i su') çirkin söz (kavl-i münker), ${ }^{162}$ yalan söz (kavl-i zûr), ${ }^{163}$ eğri söz (kavl-i lahn), ${ }^{164}$ ve süslü söz (kavl-i zuhruf) gibi niteliklerle vasiflandırılmaktadır. ${ }^{165}$

Kur'an'da emredilen ihsan da aslında insanlarla iyi muamelede bulunmak, onlara karşı hoşgörülü olmak, affetmek ve birbirine karşı saygılı olmak anlamındadır. Çünkü her ne kadar adalet, haklar konusunda insanları rahatlatsa da asıl olarak insanların gönüllerini fethedecek olan güzel üsluptur. ${ }^{166}$ Fakat burada dikkat edilmesi gereken şey, saygı dilinin ve hoşgörünün sadece Müslümanlara karşı değil, Müslüman olmayan ehli kitap gibi diğerlerine de kullanılması gerekmektedir. ${ }^{167}$ Bütün bu bilgiler esas alınarak saygıyı ifade eden ve müsamahaya dayalı bir dilin kullanılmasının, kardeşliğgin temellerinden biri olduğu kanaatindeyiz.

\section{11. İnsanî Yeteneklerde Fırsat Eşitliği Sağlamak}

İnsanlar, fitratları gereği farklı yeteneklere sahiptirler. İnsanların madenler gibi olduğunu ifade eden hadis de insanların karakterlerinin farklı olduğuna dikkat çekmekle birlikte onların farklı yeteneklere sahip olduğuna da işaret etmektedir. ${ }^{168}$ İnsanlar, kendileriyle baş başa kaldıklarında her şeyin kaynağının Allah olduğunu, Allah'a ibadet etmek, ondan gelen mesajları kabul etmek, ona itaatte bulunmak, düşünmek, araştırmak, en mükemmel olanı elde etmek, evreni incelemek ve var

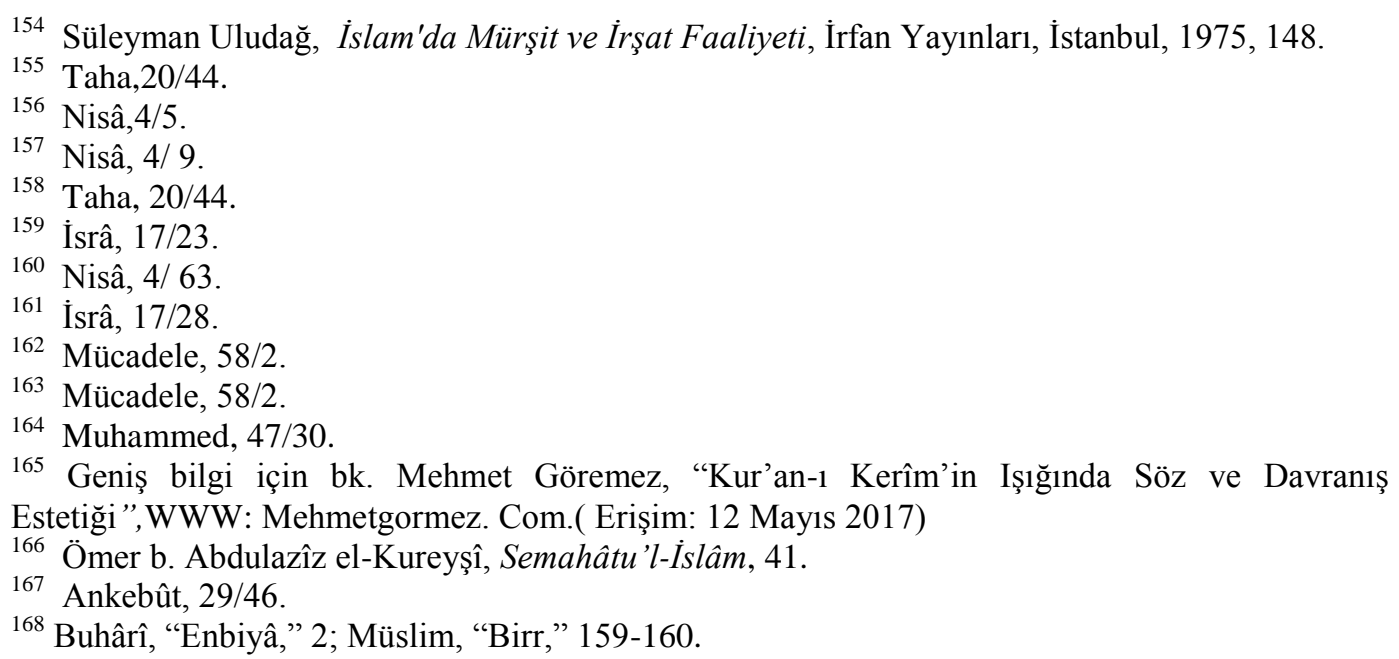


oluş nedenini araştırma gibi yeteneklerinin bulunduğunu fark edeceklerdir. ${ }^{169}$ Kur'an-1 Kerîm'de taklidin şiddetli bir şekilde eleștirilmesinin ${ }^{170}$ arkasındaki temel nedenlerden biri de insanın kendi yeteneklerini kullanmasının istenmesidir. Ancak her bireyin, yeteneklerini tam olarak ortaya koyabilmesi, firsat eşitliğinin sağlanması ve bu hususta özgür bir ortamın oluşturulmasıyla mümkün olabilir.

Hz. Peygamber'in: “Arabın aceme, beyazın siyaha üstünlüğ̈ ancak takva iledir" "171 beyanı bütün insanların yeteneklerinin bulunduğuna ve bu hususta adaletin sağlanmasının gerekliliğine işaret etmektedir. Aynı şekilde "Allah sizin şeklinize ve sermayenize bakmaz. Allah, sizin kalbinize (düşüncenizin niteliğine) ve yaptığınız işlere bakar" "172 hadisi de insanların istidatlarını ortaya koymak için firsat eşitliğinin sağlanmasına işaret ettiği söylenebilir. Çünkü bu hadiste kalpten ve işten bahsedilmesi, bilgi ve işle ilgili üretimi akla getirmektedir. Ancak bu hususta şunun bilinmesinde fayda vardır, insan yeteneklerin inkişaf etmesi ve bu yönde firsat eşitliğinin sağlanması bir bütün olarak insanların kabiliyetlerini ortaya koymakla ilgilidir. Yoksa firsat eşitliğini sağlamak bütün statüleri ve çalışma niteliğine ve iş ciddiyetine bağlı olarak oluşan farklılıkları ortadan kaldırmak anlamında değildir. Böyle bir durum insan fitratına aykırı olduğu için firsat eşitliği de sayılmaz. ${ }^{173}$

Sosyal hayatta olduğu gibi eğitim ve öğretimde de herkes için aynı şartların oluşturulması kardeşliğin bir gereğidir. İlk nazil olan âyette ${ }^{174}$ okumadan ve kalemden bahsedilmesi eğitimin önemini ortaya koymaktadır. Özellikle söz konusu âyette kalem ve yazıya yemin edilmesi ${ }^{175}$ bilgi üretimi için gereken ortamın oluşturulmasına da işaret etmektedir. et-Tevbe sûresinde geçen " Nitekim her kabileden küçük bir grubun Medine’ye gelip dini iyice ögrenmesi, sonra gidip kendi kabilesine ögretmesi ve böylece o kabilenin dini şuur ve hassasiyet kazanması daha doğru olmaz mı? "176 âyeti de eğitimde herkes için aynı şartların oluşturulmasını iktiza etmektedir. Ayrıca, en-Naziât sûresinde, gökyüzünün mükemmel yaratılması, gecede karanlığın ve gündüzde de 1şı̆̆ın varlığı, yeryüzünün düzeltilip yaşanacak bir hale getirilmesi insanların ve hayvanların yararlanması için suların yerden akıtılması, bitkilerin ve otlakların meydana getirilmesi, insanlar için olmuştur ${ }^{177}$ gibi insanın alışık olduğu olguların gündeme taşınması da firsat eşitliğine işaret etmektedir. Sonuç itibariyle insanların yeteneklerini ve istidatlarını ortaya koymak için gerekli ortamın ve şartların hazırlanmasının, kardeşliğin temel ilkelerinden biri olduğunu söylemek mümkündür.

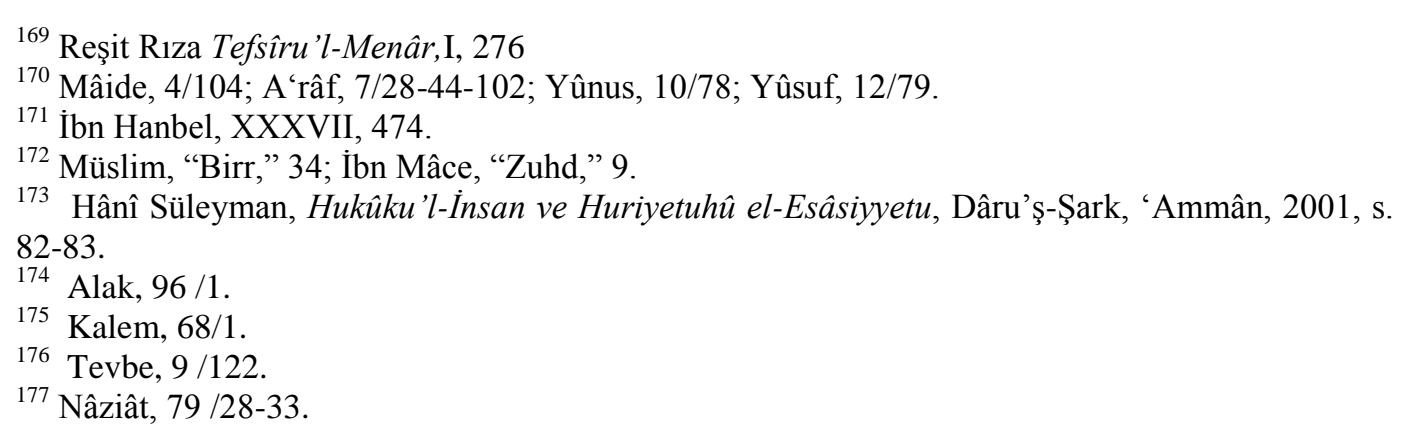




\section{Sonuç}

Kur'an-1 Kerim, insanlar arasında kardeşliği inşa ederek mutlu bir hayatın yaşandığı, güvenin hâkim olduğu, karşılıklı sorumluluğun ve yardımlaşmanın gerçekleştiği erdemli bir toplumun oluşmasını amaçlamaktadır. Ancak böyle bir toplum, Kur'an'da bahsedilen kardeşliğin temel prensiplerinin işlevsel olması ile gerçekleşebilir. Aslında bir bütün olarak insan fitratına hitap eden Kur'an, insanların kardeşliğini tesis etmeye yönelmektedir. Tarihî süreçte insanların dinleri, ırkları, dilleri, coğrafyaları, renkleri ve kültürleri farklılaşmış olsa da temel fitrî ihtiyaçlarında ve duygularında bir değişim olmamıştır. Çünkü insanlar bir bütün olarak Âdem'in çocuklarıdır ve bu yönüyle fitrî benzerlik gösterirler. Ancak bu fitrî gereksinimlerde herhangi bir haksızlığın olmaması için kardeşliğin insanî ve ahlâkî esasları dikkate alınmalıdır. Zira bu temeller üzerine bina edilmeyen bir kardeşlik anlayışı, kardeşlik hukukunun da işlevselliğini olumsuz yönde etkileyecektir.

Etkin bir kardeşliğin oluşması ve devamı için herkesin inancı gereği yaşaması ve kendini özgürce ifade edebileceği bir ortamın oluşması gerekmektedir. Fakat böyle bir zeminin oluşturulması tek başına yeterli değildir. Bununla birlikte herkes için adaleti güvenceye alan bir sistemin olması da gerekmekte ve bu durum aynı zamanda toplumsal bütünlük için de önem arz etmektedir. Çünkü adaletin olmadığı yerde kardeşlik duygularının gelişmesi zor olacaktır. Keza, her ferdin kardeşinin acısını hissetmesi ve ona bu yönde katkı sağlaması kardeşliğin önemli esaslardandır. Zira paylaşımın olmadığı ve empatinin yapılmadığı bir ortamda kardeşlik duyguları pek gelişmez. Ayrıca insanların yeteneklerini ortaya koyabilecekleri bir firsat eşitliğinin sağlanması, saygıyı ifade eden bir dilin kullanılması, toplumun yararına olabilecek değerlerin yaygınlaştırılması ve zararlı olanlarının da önlenmesi, kardeşliğin üzerine bina edildiği diğer bazı prensipleridir. Bütün bunlarla birlikte insanın fitrî haklarının korunması için mücadele edilmesi, şahsiyetinin korunması, insanlara merhamette bulunulması ve adalete tanıklık edilmesi gibi kardeşliğin esasları gerçekleştirildiğinde kardeşlik hukukunun da işlevsel olma ve topluma yansıma olasılığı artacaktır. Hâsıl-1 kelâm, insanî ve ahlâkî esaslardan yoksun bir kardeşlik anlayışı, kardeşlik hukukunun işlevselliği için gerekli zemini oluşturmayacaktır. Bu durumda nitelikli dünya imarı, güvenin hâkim olduğu erdemli bir toplumun oluşması zor olacaktır.

\section{Kaynakça}

ABDULVAHHÂB eş-Şa 'rânî, Hukuku'l-Uhuveti'l-İslâmiyye, Hamet Eker (Çev.), Sönmez Neşriyât, İstanbul, 1975.

ABDULAZÎZZ b. Osman et-Tevcîyrî, el-Keramâtu'l-İnsaniyye fi Davi'l-Mebâdii'lİslâmiyye, Menşûratu'l-Munezzameti'l-İslâmiyye li't-Terbiyyeti ve'l-Ahlâk ve'sSekâfe, Ribât, 2015.

ÂLÛSÎ, Ebu's-Senâ Şihâbüddîn Mahmûd b. Abdillâh b. Mahmûd el-Hüseynî. Rûhu'l-Me 'ânî fi Tefsîri'l-Kur'ân ve's-Seb 'i'l-Mesânî, Dâru'r-Risâle, Beyrut, 2015.

ASLAN, Ahmet. "İnsan Haklarl ve İslâm”, www: libertedownload.com. (Erişim: 1 Ocak 2018.)

BUHÂRÎ, Ebû Abdillâh Muhammed b. İsmâîl b. İbrâhîm Cu'f î, Cami'ü’s-Sahîh, el-Matba'atü'l-Kübrâ'l-Emîriyye, Bulak, 1895. 
Ed-DÂMİĞÂNî, Ebû Abdillah Hüseyin Muhammed, el-Vucûh ve'n-Nezâir, Mahummed Hasan Ebü'l-Azm ez-Zeftî (thk.), Metabî‘u'l-Ehrâm, Kahire, 1996.

DEMIRCI, Muhsin, Kur'an ve Sünnete Göre Temel Insan Haklart, Ensar Neşriyat, İstanbul, 2014.

EBÛ HİLÂL, Hasan b. Abdullah b. Sehl Askerî, el-Furûku'l-Luğaviyye, Muhammed Bâsıl 'Uyûn's-Sûd (thk.), Dâru'l-Kutûbu'l-'İlmiyye, Beyrut, 2010.

EBÛ DÂVÛD, Süleyman b. Eş'as b. İshâk Ezdî Ebû Dâvûd Sicistânî, Sünen. Dârü's-Selâm, Riyâd, 2008.

EBÛ ZEHRA, Muhammed b. Ahmed b. Mustafa Muhammed, Zehretu't-Tefâsir. Dâru'l-Fikri'l-Arabî, Kahire, ts.

EBÜ'T-TAYYİB Muhammed Siddîk Bahâdır Han b. Hasen b. Ali el-Kannevcî, Fethu'l-Beyân fi Mekâsidi'l-Kur'an, Abdullah b. İbrahim(thk.), el-Mektebetu'lAsriyye, Beyrut, 1992.

EBÜ'L-HASEN Alî b. Muhammed b. Alî es-Seyyid eş-Şerîf el-Cürcânî. etTarifât. Mektebetu Lubnân, Beyrut, ts.

EZHERÎ, Ebû Mansûr Mahmud b. Ahmed. Tehzîbu'l-Lŭga, Abdulhalîm enNeccâr (thk.), ed-Dâru'l-Misriyye, yy, 1964.

GÖRMEZ, Mehmet, Kur'an-ı Kerîm'in Işı̆̆ı̆nda Söz ve Davranış Estetiği, www:mehmetgormez. com. (Erişim: 12 Mayıs 2017)

HALÎL B. AHMED el-Ferâhîdî. Kitâbu'l-Ayn. Abdulhamîd el-Hindâvî (thk.), Dâru'l-Kutûbu'l-'İlmiyye, Beyrut, 2003.

HÂNÎ Süleyman, Hukûku'l-İnsân ve Hurriyetuhû'l-Esâsiyye, Dâru'ş-Şark, 'Ammân, 2001.

HASAN EL-BÂŞ, el-Aklu ve Hivâru'l-Kur'ân, Dâru'l-Vataniyye, Bingâzî, ts.

İBN FÂRIS, Ebü'l-Hüseyin Ahmed b. Fâris b. Zekeriyyâ, Mu 'cemu Makâyîsi'lLuğa, Muhammed Murîb ve Fatime Muhammed (thk.), Dâru İhyâi't-Turâsi'lArabî, Beyrut, 2001.

İBN ATIYYYE, Ebû Muhammed Abdülhak b. Gālib b. Abdirrahmân b. Gālib elMuhâribî el-Girnâtî el-Endelüsî, el-Muharreru'l-Vecîz fî̀ Kitâbihi'l-Azîz, Abdusselâm Abduşşâfî̀ (thk.), 1.bs., Dâru'l-Kutûbi'l-İlmiyye, Beyrut, 2001.

İBN ADİL, Ebû Hafs Ömer b. Ali ed-Dımaşkî, el-Lübâb fî 'Ulûmi'l-Kitâb, Dâru'l-Kutûbi'l-İlmiyye, Beyrut, 1998.

İBN TEYMIYYE, Ebü'l-Abbâs Takıyyüddîn Ahmed b. Abdilhalîm b. Mecdiddîn Abdisselâm el-Harrânî, Mecmû 'u'l-Fetâvâ, Mektebetü'l-Ubeykân, Riyad, 1997.

İBN MANZÛR, Ebü'l-Fazl Muhammed b. Mükerrem b. Ali el-Ensârî, Lisânu'lArab, Dâru İhyâi't-Turâsi'l-Arabî, Beyrut, 1997.

İSFAHÂNÎ, Ebü'l-Kāsım Hüseyn b. Muhammed b. el-Mufaddal er-Râgıb, Mufredâtu Elfâzi'l-Kur'ân, Safvân 'Adnan Dâvûdî (thk.), Dâru'l-Kalem, Dımaşk, 2002.

----------Ez-Zerîyga ile Mekârîmi 'ş-Şerîya, Dâru İkra, Dımaşk, 2001.

İBN MÂCE, Ebû Abdullah Muhammed b. Yezîd er-Rebei el-Kazvinî, Sünen, elMatbaü'n-Nizâmî, Delhi, 1905.

İBN ÂŞÛR, Muhammed Tahirb. Muhammed b. Muhammed et-Tunûsî, etTahrîrve't-Tenvîr, ed-Dâru't-Tunusiyye, Tunus, 1984.

İBN KAYYIM EL-CEVZIYYY, Ebû Abdullah Şemseddin Muhammed, I'lâmü'l Muvakkı 'in an Rabbi'l-Alemîn, Muhammed es-Selâm İbrahim (thk.), Dâru'lKutubi'l-İlmiyye, Beyrut, 1996. 
İBN SEYYİDÜNNÂS, Ebu'l-Feth Fethuddin Muhammed b. Muhammed, Uyûnu'l-Eser fî Funûni'l-Megâzî ve'ş-Şemâil ve's-Siyer, Muhyeddin Misto (thk.), Dârü'l-Âfâkı'l-Cedîde, Beyrut, 1982.

İNAN, Ahmet, Insan Haklarl ve Din, Çanakkale Üniversitesi Yayınları, Çanakkale, 2010.

İSMAİL Ali Muhammed, el-Uhuvvetu'l-İslâmiyye Ferîydetun Şer'iyye ve Darûretun 'Asriyye, Dâru'l-Kelime, Kahire, 2012.

KÖSE, Saffet, "Kardeşlik Hukuku (fikıh boyutu)". Hz. Peygamber Kardeşlik Ahlakı ve Kardeşlik Hukuku Sempozyumu Bildirileri, DİB Yayınları, Ankara, 2012, 123-148.

KORUKÇU, Âdem, “İslâm'da Kardeşlik Hukuku ve Kardeşlikten Doğan Haklar", Kutlu Doğum Haftası Hz. Peygamber Kardeşlik Ahlakı ve Kardeşlik Hukuku Sempozyumu Bildirileri, DİB Yayınları, Ankara, 2012, 140-164.

EL-KURTUBÎ, Ebû Abdillâh Muhammed b. Ahmed b. Ebî Bekr b. Ferh, elCâmi ' li-Ahkâmi’l-Ķur'ân, Abdullah b. Abdulmuhsin et-Türkî (thk.), Muessesetu Risâle, Beyrut, 2013.

KASIMÎ, Cemâleddin Muhammed b. Muhammed Saîd Cemâleddin, Mehâsinü'tte'vil, Dâru'l-Kutubi'1-'İlmiyye, Beyrut, 2003.

Mâtürîdî, Ebû Mansûr Muhammed b. Muhammed b. Mahmûd Mâtürîdî SEMERKANDÎ, Te 'vilâtu'l-Kur'an, Bekir Topaloğlu ve Ahmed Vanlıoğlu (thk.), Dâru'l-Mizân, İstanbul, 2005

MUHAMMED EBÛ ZEHRA, el-Mucteme 'u'l-İnsanî fì Zilli'l-İslâm, Dâru'sSuûdiyye, Riyâd, 1981.

MUHAMMED CEVVÂD Muğniyye, et-Tefsîru'l-Kâşsif, Dâru'l-İlm li'l-Melâyîn, Beyrut, 1999.

MUHAMMED FUÂD Abdulbâkî, el-Mu'cemu'l-Mufehres li Elfâzi'l-Kur'an-i'lKerîm, Dâru'l-Hadis, Kahire, 1987.

MUKATILL b. Süleyman, Tefsir-i Kebîr, Dâru'l-Kutubi'l-İlmiyye, Beyrut, ts.

MUHAMMED KUTUP Tabliye, el-íslâm ve Hukûku'l-İnsan, Dâru'l-Fikri'lArabi, yy., 1984.

MALİK b. Enes, Ebû Abdullah el-Asbehî el-Himyerî, Muvatta, Beşşâr 'Avvâd Ma'rûf, Mahmûd Muhammed Halîl (thk.), Müessesetü'r-Risâle, Beyrut,1992.

ÖMER b. Abdulazîz el-Kureyşî, Semahâtu'l-İslâm, Mektebetu'l-Edîb, Riyâd, 2006.

ÖNDER, Mustafa, "Kur'an ve Sünnette İnsan Onuruna Eğitim Açısından Yaklaşım”, Amasya Üniversitesi İlâhiyat Fakültesi Dergisi Cilt: 2 sy: 4, 2015, s.37-55.

RÂẐ̂, Ebû Abdullah Fahreddin Muhammed b. Ömer Fahreddin, Mefâtihu'lGayb, Dâru'l-Fikr, Beyrut, 1981.

RAĞIB Sercânî, el-Klyem ve'l-Ahlâk fî'l-Hadâreti'l-İslâmiyye, www: raoulallah.net.( Erişim: 15 Mayıs 2017)

SAYAR, Kemal, Merhamet, Timaş Yayınları, İstanbul, 2013.

SEYYID b. Kutub b. İbrâhim Seyyid Kutub, Fî zilâli'l-Kur'an, Dâru'ş-Şurûk, Kahire, 2004.

TABERÎ, Ebû Cafer İbn Cerîr Muhammed b. Cerîr b. Yezid, Câmi 'u'l-Beyân 'an Te'vîli Âyi'l-Kur'ân, Mahmut Muhammed Şakir ve Ahmet Muhammed Şakir (thk.), Mektebetü İbnTeymiyye, Kahire, ts. 
TOSHILIKKO İİTSU, Kur'an'da dini ve Ahlâkî Kavramlar, Pınar Yayınları, İstanbul, 2003.

TİRMIZÎ, Ebû İsâ Muhammed b. İsâ b. Sevre es-Sülemî, Sünen, Kahire, 1937.

Uludağ, Süleyman, İslâm'da Mürşit ve İş̧at Faaliyeti, İrfan Yayınları, İstanbul, 1975.

YÜKSEL, Mehmet, Hukuk Sosyolojisi, Anadolu Üniversitesi Tesisleri, Eskişehir, 2012.

YUSUF KARADÂVÎ, el-Klyemu'l-İnsaniyye fi'l-İslâm, http: www.alqaradawi.net. (Erişim: 12. Aralık 2017.)

YOLAÇAN, Semih, İslâm Kültüründe Kardeşlik Ruhu, Ekrem Yayınları, İstanbul, 2006.

ZEMAHŞERÎ, Ebü'l-Kasım Carullah Mahmûd b. Ömer b. Muhammed. el-Keşşâf an Hakâikı Gavâmizi't-Tenzîl ve Uyûni'l-Ekâvil fì Vücûhi't-Te'vil, Dâru'lKutûbi'l-İlmiyye, Beyrut, 2015, -El-Esâsu fì'l-Belâğa, Dâru Sâdır, Beyrut, 1965. 